\title{
How fast is fast enough? Twitter usability during emergencies
}

Santoni, V., \& Rufat, S. (2021). How fast is fast enough? Twitter usability during emergencies. Geoforum, 124, $20-35$. https://doi.org/10.1016/j.geoforum.2021.05.007

Victor Santoni, CY Cergy-Paris University, MRTE, 33 Boulevard du Port, 95000, Cergy-Pontoise, France, victor.santoni@,cyu.fr

Samuel Rufat, CY Cergy-Paris University, MRTE; Institut Universitaire de France, 1 rue Descartes, 75231 Paris, France, samuel.rufat@u-cergy.fr

\begin{abstract}
Social media have sparked increasing appeal for improving emergency management. Many have advocated the use of Social Media for Emergency Management (SMEM) to disseminate early warnings. Resorting to the massive but unstructured inVoluntary Geographic Information (iVGI) from social media during disaster response phase has been encouraged for rapid assessment, location and mapping of people and events, for monitoring the expressed needs and for observing human behavior in crisis dynamics. SMEM encompasses top-down - public information, community engagement - bottom-up - situational awareness, urgent needs collection - and many-to-many information flows - allowing a large number of users to communicate with each other simultaneously in real-time. However, operationalizing social media data in real-time during emergency situations might not be as practical as ex post facto retrospective analyses usually suggest. We question the use of SMEM and the unchallenged expectations that they allow for a faster and more widespread dissemination of early warnings, more citizens involvement and offer a richer and more contextualized crowdsourced feedback than classic emergency channels. We analyze the usefulness of geotagged information to monitor the unfolding of a crisis in real time and to accurately detect events and map people. We also question if the use of social media for emergency management is conditioned by local context and governance, by making a comparison between European countries. We offer a critical review of the literature, an SMEM analytical framework, and then empirical work based on large Twitter datasets collected from three different terror attacks in Europe: the Paris attacks in November 2015, the Brussels attacks in March 2016, and the Nice attack in July 2016. The results reveal important delays in warnings and information sharing, and that the press overshadows official accounts. Moreover, first-hand information is often too scattered, too thinly geotagged, and too late to be reliably used during emergency situations.
\end{abstract}

Keywords: Social media, Emergency management, iVGI, Big data, Attacks, Early warning, Disasters

\section{Introduction}

After a series of terror attacks and false alarms, the French national early warning mobile application was discontinued in 2017. After this application was discredited by a series of failures and delays in sending warnings (Douvinet et al., 2020), many have advocated the use of social media for emergency management (SMEM) to disseminate early warnings. The French government subsequently signed agreements with Twitter, Facebook and Google to develop crisis communications ${ }^{1}$. In the US, (Graham et al., 2015) survey shows that $71 \%$ out of 307 local

1The French Ministry of Interior partners with major actors to warn populations in case of an emergency - Press release (in French) (May 2018) https://www.interieur.gouv.fr/fr/Actualites/Information-de-la-population-en-cas-de-danger/ 
governments engage social media for crisis communication purpose. Other countries had already chosen a similar path, like New Zealand (Rive et al., 2012). Being able to collect the massive amount of data from social media looked like a major opportunity for emergency management (Liu et al., 2008; Palen et al., 2009).

Resorting to social media in real time during disaster response and early recovery phases has also been encouraged to gain situational awareness to be used for rapid assessment, location and mapping of people and events, as well as for the monitoring of expressed needs and for detecting human behavior in crisis dynamics. SMEM encompasses top-down - public information, community engagement - bottom-up - situational awareness, urgent needs collection - and manyto-many information flows - allowing a large number of users to communicate with each other simultaneously in real-time. As an example, after the Jakarta floods from 2013 to 2015, many-tomany flows were used to reveal the difference between official information and users' geotagged tweets about shelter locations (Kusumo et al., 2017). Recent investigations use social media data in post-disaster assessments, aggregating, mapping and exploring the inherent complexities and spacetime dynamics of emergencies and disasters. Geotagged tweets are collected to better understand human activity during a disaster event, the spatial and temporal patterns of digital trails are used to monitor the evolution of the crisis, while content or metadata (such as hashtags, followers, shares, multimedia, etc.) are extracted to increase understanding, improve situational awareness, or for interaction and network analysis. Geotagging, access, scope and speed often make Twitter a favored channel. However, monitoring and operationalizing social media data in real time during emergency situations might not be as practical as ex post facto retrospective analyses usually suggest. Major challenges arise from practical issues that are too often overshadowed by the novelty effect.

In this paper, we question the use of social media and the unchallenged expectations that they allow for a faster and more widespread dissemination of early warnings. We also question other common expectations, that social media foster citizens involvement and offers a richer and more contextualized crowdsourced feedback than classic emergency channels during emergency management. We also explore the usefulness of geotagged information to monitor the unfolding of a crisis in real time and to accurately detect event and map people. Finally, we question if the use of social media for emergency management is conditioned by local context and governance, which is currently not addressed in the existing literature, by making a comparison between France and Belgium. We start with a critical review of the literature, an SMEM analytical framework, and then present an empirical work based on Twitter datasets collected from three different terror attacks: the Paris attack in November 2015, the Brussels attacks in March 2016, and the Nice attack in July 2016.

\section{Crowdsourcing and crowd mapping in emergency management and disaster relief}

Emergency management is the process of "developing and implementing policies that are concerned with mitigation, preparedness, response and recovery" (Petak, 1985) regarding crises and disasters. Emergency management concerns every geographic levels of government (local, regional, and federal) and requires the efforts of many disciplines to overcome disasters consequences. As such, emergency management systems include a crisis cell with decision-makers, public and private stakeholders providing expertise, communication system ensuring the information flows, and firstresponders tackling the event on the field (Lagadec, 1995).

During the past decade, volunteered geographic information (VGI) has led to consider citizens as sensors (Elwood, 2008; Goodchild, 2007). VGI had early successes in emergency management, most notably through Open Street Map (Zook et al., 2010) or Ushahidi (Okolloh, 2009). VGI was 
so successful, fast and cheap that the US government decided to use such crowdsourced information for coordinating international disaster relief in the aftermath of the 2010 earthquake in Haiti (Yates and Paquette, 2011). However, despite the expectations generated by early successes, VGI remains limited of its demographic bias (Li et al., 2013), because of its spatial bias induced by the volunteers opportunistic observation effort (Zhang and Zhu, 2018), and because of the number of volunteers.

Twitter is a microblogging social media platform where users can post short messages named tweets. It is quite successful in academic research (Acar and Muraki, 2011; Kryvasheyeu et al., 2015; Li et al., 2013; Takahashi et al., 2015; Zhang and Zhu, 2018, etc.). Firstly, because the wide majority of tweets are public, and secondly, because metadata can be extracted through many application programming interfaces (API). Despite the expectations generated by early successes, VGI remains limited because of its demographic bias resulting from the lack of representativeness of contributors' profile among the total population ( $\mathrm{Li}$ et al., 2013), because of its spatial bias induced by the volunteers' opportunistic observation effort (Zhang \& Zhu, 2018), and because of the reduced number of volunteers. User-generated information from the field evolved from being limited but well-structured VGI, to being massive but unstructured across social media. Such information is referenced as "involuntary geographic information" (iVGI) (Fischer, 2012) because users do not have any control on how their data will be used after being posted. With Twitter, in addition to semantic information within tweets, geographic information is to be found in the metadata: Internet access point, latitude / longitude, and/or voluntary geotags provided by the user (Bouillot et al., 2012). Collecting and refining Twitter's geographic information is an ongoing effort (Williams et al., 2017) to make tweets relevant for geospatial analysis (Saldana-Perez et al., 2019). Tweets are used in many domains such as human mobility (Luo et al., 2016), detecting population density at different times (Landwehr et al., 2016), or even predicting pandemic outbreaks (Zhao et al., 2016).

Twitter data was used as a "sensor" after Hurricane Sandy to collect geospatial data on the impacted areas (Albuquerque et al., 2015; Kryvasheyeu et al., 2015), with a positive correlation between Twitter activity and per-capita disaster damage (Kryvasheyeu et al., 2016). However, other studies cross-referencing Twitter data with surveys after the Tohoku earthquake in Japan (Acar and Muraki, 2011) or Typhoon Haiyan in the Philippines (Takahashi et al., 2015) revealed a variety of uses: people in affected areas tweet more about unsafe and uncertain conditions, while people in remote areas tweet about being safe. Social media are nevertheless mostly used to disseminate second-hand information and to memorialize those affected. Twitter data has been used as a VGI substitute, to identify the shelter locations preferred by flood evacuees in Jakarta for instance (Kusumo et al., 2017). In fact, SMEM have found applications in every disaster phase (Landwehr et al., 2016). Twitter data has even been used for detecting earthquakes in real time (Sakaki et al., 2010). In Belgium and France however, fewer studies address SMEM as of today. While very few analyses of the bottom-up and many-to-many information flows have been done so far (Santoni and Audoin, 2017), geographers have teamed up with first-responders to improve top-down early warning uses or to test possible mapping applications (Douvinet et al., 2017).

Top-down SMEM flow encompass early warnings' and official posts or information from emergency managers accounts during a disaster (Rive et al., 2012). Bottom-up SMEM flow is the user-generated information addressed to emergency managers accounts. It can include three cases: answers to emergency manager posts, direct messages to official accounts, or tags referencing emergency manager accounts to call on them or to draw their attention to some post or media content (Rive et al., 2012). Many-to-many SMEM flow refers to all the content posted by all social media users (many) about a crisis or an emergency without targeting a specific audience (many). Such information can be monitored or harvested in bulk as soon as the relevant keywords, hashtags, 
or geotags referring to the event and location have been identified (SPFI, 2015). While many-tomany flows are accessible to all users and might include relevant information, users might not have produced it with the objective to help or call on first-responders. They might not even be fully aware of the situation. Emergency managers expect users to spontaneously and promptly share firsthand media-rich information during unusual events.

\section{Social Media for Emergency Management: Debate and Bias}

While the sheer volume of social media data has raised high expectations for emergency management, there is a debate opposing "big data" and "small data" (Kitchin and Lauriault, 2015), or even "micro" datasets (Tsou and Leitner, 2013) that generate significant results with less than 350 tweets (De Longueville et al., 2009). We argue that this debate is about focus rather than size. Social media data can be examined through a "telescope", with high volume quantitative analysis, or through a "microscope", with qualitative analysis and/or focusing on the granularity of the individual (Beckouche, 2019). Such debates derive four possible biases in SMEM:

Bias 1: "Big data" is not whole data (boyd and Crawford, 2012), meaning that social media users are not an average representation of the population. Socio-spatial inequalities have been highlighted, with whiter, wealthier, tourist-oriented users during Hurricane Katrina (Crutcher and Zook, 2009) and with blacker and wealthier users during the Michael Brown case (Bunting and Stamatel, 2019). Such inequalities reflect Twitter "data shadows" (Shelton et al., 2014). While physically vulnerable communities had more intense responses on social media during Hurricane Sandy, socially vulnerable communities were digitally left behind (Wang et al., 2019). On the other side, non-human accounts, i.e. bots or automated accounts that are used for mechanically producing, promoting or manipulating specific information weigh and visibility, are also tweaking data accuracy and representativeness (Crawford and Finn, 2015).

Bias 2: Social media are plagued by noise, rumors and false flags (Starbird et al., 2014; Vicario et al., 2016). Inaccurate Twitter geographic information and subsequent retweets induce noise, SMEM can consequently hinder post-disaster data collection and response rather than improve it (Earle et al., 2010). However, it has been argued that noise and rumors are not such a concern because of a self-correcting mechanism in social media: as users correct inaccuracies and dispel rumors, the sheer number of users is expected to be working as a safety net to correct the information flow (Jong and Dückers, 2016).

Bias 3: Social media might lead to over-communication and backfire during an emergency, generating stress and panic (Spence et al., 2015). Conversely, minimal social media communication gives free rein to rumors and has been shown to have detrimental impacts (Jones et al., 2017).

Bias 4: Twitter geotagged information only represents between $0.7 \%$ (Graham et al., 2014) to 6\% (Takhteyev et al., 2012) of a total volume of tweets. Some studies have tried to circumvent this by using the profile location in addition to the tweets thin geospatial data (Sakaki et al., 2010; Williams et al., 2017; Zou et al., 2018) or text analytics (Bahir and Peled, 2016). However, the "lack of correlation between profile and device location" (Graham et al., 2014) casts doubts on their conclusions. Moreover, putting a tweet on a map is insufficient to explain complex socio-spatial relations (Crampton, 2015), and the statistical correlation between population density and geotagged tweets might generate false positive (Li et al., 2013). In addition, (Yuan et al., 2020) are showing that tweets located in places with predefined coordinates are $44 \%$ off-scene. 
Santoni, V., \& Rufat, S. (2021). How fast is fast enough? Twitter usability during emergencies. Geoforum, 124, $20-35$.

\begin{tabular}{|c|c|c|c|c|c|c|c|c|c|c|c|}
\hline Event & Year & Disaster type & Duration & Scope & $\begin{array}{l}\text { Affected } \\
\text { people }\end{array}$ & $\begin{array}{c}\text { Prior } \\
\text { Warning }\end{array}$ & Literature & Bias 1 & Bias 2 & Bias 3 & Bias 4 \\
\hline Earthquake Haiti & 2010 & Earthquake & Days & National & 1000000 & No & $\begin{array}{c}\text { Yates and } \\
\text { Paquette, } 2011\end{array}$ & $\begin{array}{c}\text { Not } \\
\text { addressed }\end{array}$ & $\begin{array}{c}\text { Not } \\
\text { applicable }\end{array}$ & $\begin{array}{c}\text { Not } \\
\text { applicable }\end{array}$ & $\begin{array}{c}\text { Not } \\
\text { addressed }\end{array}$ \\
\hline $\begin{array}{l}\text { South Carolina } \\
\text { Wildfires }\end{array}$ & 2007 & Fire & Months & Regional & 10000 & Yes & $\begin{array}{c}\text { Sutton et al., } \\
2008\end{array}$ & $\begin{array}{c}\text { Not } \\
\text { addressed }\end{array}$ & Yes & $\begin{array}{c}\text { Not } \\
\text { applicable }\end{array}$ & $\begin{array}{c}\text { Not } \\
\text { addressed }\end{array}$ \\
\hline Riot Venezuela & 2014 & Riot & Months & National & 1000 & No & $\begin{array}{c}\text { Debos and } \\
\text { Lancini, } 2017\end{array}$ & $\begin{array}{c}\text { Not } \\
\text { addressed }\end{array}$ & $\begin{array}{c}\text { Not } \\
\text { addressed }\end{array}$ & Yes & $\begin{array}{l}\text { Not } \\
\text { addressed }\end{array}$ \\
\hline $\begin{array}{l}\text { Boston } \\
\text { Marathon } \\
\text { bombing }\end{array}$ & 2013 & Attack & Minutes & Local & 100 & No & $\begin{array}{c}\text { Starbird et al., } \\
2014\end{array}$ & $\begin{array}{c}\text { Not } \\
\text { addressed }\end{array}$ & Yes & Yes & $\begin{array}{c}\text { Not } \\
\text { addressed }\end{array}$ \\
\hline $\begin{array}{l}\text { Flash flood } \\
\text { France }\end{array}$ & 2010 & Flash flood & Hours & Local & 100 & Yes & $\begin{array}{l}\text { Douvinet et al., } \\
2017\end{array}$ & $\begin{array}{c}\text { Not } \\
\text { addressed }\end{array}$ & $\begin{array}{c}\text { Not } \\
\text { addressed }\end{array}$ & Yes & $\begin{array}{l}\text { Not } \\
\text { addressed }\end{array}$ \\
\hline $\begin{array}{c}\text { Gunman in the } \\
\text { Newsroom }\end{array}$ & 2015 & Hostage & Hours & Local & 10 & No & $\begin{array}{c}\text { Jong and } \\
\text { Dückers } 2016\end{array}$ & $\begin{array}{c}\text { Not } \\
\text { addressed }\end{array}$ & Yes & Yes & $\begin{array}{c}\text { Not } \\
\text { addressed }\end{array}$ \\
\hline Hurricane Sandy & 2012 & Hurricane & Days & International & 1000000 & Yes & $\begin{array}{c}\text { Wang et al., } \\
2019\end{array}$ & Yes & $\begin{array}{c}\text { Not } \\
\text { addressed }\end{array}$ & $\begin{array}{c}\text { Not } \\
\text { addressed }\end{array}$ & Yes \\
\hline $\begin{array}{c}\text { Tohoku } \\
\text { Earthquake \& } \\
\text { Tsunami }\end{array}$ & 2011 & Earthquake & Minutes & International & 100000 & Yes & $\begin{array}{c}\text { Acar and } \\
\text { Muraki, } 2011\end{array}$ & Yes & Yes & $\begin{array}{c}\text { Not } \\
\text { addressed }\end{array}$ & $\begin{array}{c}\text { Not } \\
\text { addressed }\end{array}$ \\
\hline Flood Jakarta & 2013 & Flood & Days & Regional & 100000 & No & $\begin{array}{c}\text { Kusumo et al., } \\
2017\end{array}$ & Yes & Yes & $\begin{array}{c}\text { Not } \\
\text { addressed }\end{array}$ & Yes \\
\hline $\begin{array}{l}\text { Hurricane } \\
\text { Katrina }\end{array}$ & 2005 & Hurricane & Days & Regional & 100000 & Yes & $\begin{array}{l}\text { Crutcher and } \\
\text { Zook, } 2009\end{array}$ & Yes & $\begin{array}{c}\text { Not } \\
\text { addressed }\end{array}$ & $\begin{array}{c}\text { Not } \\
\text { applicable }\end{array}$ & Yes \\
\hline $\begin{array}{l}\text { Flash flood South } \\
\text { Carolina }\end{array}$ & 2015 & Flash flood & Days & Regional & 10000 & Yes & $\begin{array}{l}\text { Zhenlong et al., } \\
2017\end{array}$ & Yes & $\begin{array}{c}\text { Not } \\
\text { addressed }\end{array}$ & $\begin{array}{c}\text { Not } \\
\text { addressed }\end{array}$ & $\begin{array}{c}\text { Not } \\
\text { addressed }\end{array}$ \\
\hline European floods & 2011 & Flood & Days & International & 10000 & Yes & $\begin{array}{c}\text { Rizza et } \\
\text { Pareira, } 2014\end{array}$ & Yes & $\begin{array}{c}\text { Not } \\
\text { addressed }\end{array}$ & $\begin{array}{c}\text { Not } \\
\text { addressed }\end{array}$ & $\begin{array}{l}\text { Not } \\
\text { addressed }\end{array}$ \\
\hline Ferguson unrest & 2014 & Riot & Months & Local & 100 & No & $\begin{array}{c}\text { Bunting and } \\
\text { Stamatel, } 2019\end{array}$ & Yes & $\begin{array}{c}\text { Not } \\
\text { addressed }\end{array}$ & $\begin{array}{c}\text { Not } \\
\text { addressed }\end{array}$ & Yes \\
\hline $\begin{array}{l}\text { Horsethief } \\
\text { Canyon fire }\end{array}$ & 2012 & Fire & Days & Local & 10 & No & $\begin{array}{c}\text { Kent and } \\
\text { Capello, } 2013\end{array}$ & Yes & Yes & $\begin{array}{c}\text { Not } \\
\text { addressed }\end{array}$ & $\begin{array}{c}\text { Not } \\
\text { addressed }\end{array}$ \\
\hline
\end{tabular}

\begin{tabular}{|c|c|c|c|c|}
\hline Scope Duration & Minutes & Hours & Days & Months \\
\hline Local & $\begin{array}{l}2013 \text { Boston Bombing } \\
\text { (Starbird et al., 2014) } \\
2016 \text { Nice Attack }\end{array}$ & $\begin{array}{c}2010 \text { Flash flood France } \\
\text { (Douvinet et al., 2017) } \\
2015 \text { Gunsman in the newsroom } \\
\text { (Jong and Dückers, 2016) } \\
2015 \text { Paris Attacks } \\
2016 \text { Brussels Attacks }\end{array}$ & $\begin{array}{l}2012 \text { Canyon Fire } \\
\text { (Kent and Capello, 2013) }\end{array}$ & $\begin{array}{l}\text { 2014 Fergusson unrest } \\
\text { (Bunting and Stamatel, } \\
\text { 2019) }\end{array}$ \\
\hline Regional & & $\begin{array}{l}2013 \text { \& } 2014 \text { Floods in Jakarta } \\
\text { (Kusumo et al., 2017) }\end{array}$ & $\begin{array}{c}2005 \text { Hurricane Katrina } \\
\text { (Crutcher and Zook, 2009) } \\
2015 \text { South Carolina floods } \\
\text { (Zhenlong et al., 2017) }\end{array}$ & $\begin{array}{l}2007 \text { South Carolina } \\
\text { wildfires (Sutton et al., } \\
\text { 2008) }\end{array}$ \\
\hline National & & & $\begin{array}{c}2010 \text { Earthquake Haiti } \\
\text { (Yates and Paquette, 2011) }\end{array}$ & $\begin{array}{c}2014 \text { Riot Venezuela } \\
\text { (Debos and Lancini, 2017) }\end{array}$ \\
\hline International & & $\begin{array}{l}2011 \text { Tohoku Earthquake and } \\
\text { Tsunami } \\
\text { (Acar and Muraki, 2011) }\end{array}$ & $\begin{array}{l}2012 \text { Hurricane Sandy } \\
\text { (Wang et al., 2019) } \\
2011 \text { European floods } \\
\text { (Rizza et Pareira, 2014) }\end{array}$ & \\
\hline
\end{tabular}




\begin{tabular}{|c|c|c|c|c|c|c|}
\hline $\begin{array}{l}\text { Affected } \\
\text { people } \\
\text { Warning }\end{array}$ & $10 \mathrm{~s}$ & $100 \mathrm{~s}$ & $1000 \mathrm{~s}$ & 10 000s & $100000 \mathrm{~s}$ & Millions \\
\hline No prior warning & $\begin{array}{l}2012 \text { Canyon Fire } \\
\text { (Kent and Capello, } \\
\text { 2013) } \\
2015 \text { Gunsman in } \\
\text { the newsroom } \\
\text { (Jong and Dückers, } \\
\text { 2016) }\end{array}$ & $\begin{array}{c}2013 \text { Boston } \\
\text { Bombing } \\
\text { (Starbird et al., 2014) } \\
2014 \text { Fergusson } \\
\text { unrest } \\
\text { (Bunting and } \\
\text { Stamatel, 2019) }\end{array}$ & $\begin{array}{c}2014 \text { Riot } \\
\text { Venezuela } \\
\text { (Debos and Lancini, } \\
\text { 2017) } \\
2016 \text { Nice Attack }\end{array}$ & $\begin{array}{l}2015 \text { Paris Attacks } \\
2016 \text { Brussels Attacks }\end{array}$ & $\begin{array}{c}2013 \text { \& } 2014 \text { Floods } \\
\text { in Jakarta } \\
\text { (Kusumo et al., 2017) }\end{array}$ & $\begin{array}{c}2010 \text { Earthquake Haiti } \\
\text { (Yates and Paquette, 2011) }\end{array}$ \\
\hline Prior warning & & & $\begin{array}{l}2010 \text { Flash Flood } \\
\text { France } \\
\text { (Douvinet et al., } \\
\text { 2017) }\end{array}$ & $\begin{array}{l}2007 \text { South Carolina } \\
\text { wildfires (Sutton et al., } \\
\text { 2008) } \\
2011 \text { European floods } \\
\text { (Rizza et Pareira, 2014) } \\
2015 \text { South Carolina } \\
\text { floods (Zhenlong et al., } \\
\text { 2017) }\end{array}$ & $\begin{array}{c}2011 \text { Tohoku } \\
\text { Earthquake and } \\
\text { Tsunami } \\
\text { (Acar and Muraki, } \\
\text { 2011) } \\
2005 \text { Hurricane } \\
\text { Katrina (Crutcher and } \\
\text { Zook, 2009 }\end{array}$ & $\begin{array}{l}2012 \text { Hurricane Sandy } \\
\text { (Wang et al., 2019) }\end{array}$ \\
\hline
\end{tabular}

Fig.1 Analytical SMEM Framework

We propose an analytical framework to appraise how the SMEM biases are addressed in the literature and relevant across case studies (fig. 1). The framework is split into three dimensions to capture how the biases are addressed (fig. 1A), to assess the geographical scope and duration of the events considered in the literature (fig. 1B), as well as the number of affected people, and the existence of prior warnings (fig. 1C). While the path of Hurricane Sandy was correctly predicted and official warnings issued, this is not possible for other events, especially earthquakes or attacks. We populated the framework with two case studies per disaster type. To the best of our knowledge, no study tackles all the SMEM biases at once, as the fourth bias is often overlooked (fig. 1A). Conversely, most studies address the first bias. While terror attack and hostage situation case studies did not address this bias, it does not seem to derive from any specific disaster type. Studies addressing the third bias seem to focus on local events with less than 1000 affected people, whereas biases 2 and 4 do not translate into any specific pattern. It is worth mentioning that studies from before the creation of the relevant emergency managers social media accounts - and any before 2009 - could not explicitly address bias 3, as top-down SMEM communication was not previously possible. We could not find studies for all the scope and duration combinations (fig. 1B), the covid19 pandemic should promptly fill one of the identified gaps though. While riots and attacks are difficult to predict, other events are preceded by prior warnings (fig. 1C) and disseminating official early warnings over social media is less relevant for the latter. There are currently no commons indicators in the literature to assess the reactions in social media to the variety of disasters, warnings, their scopes, duration, or number of affected people.

As a result of some of these biases, many have argued that social media data has to be crossreferenced with a precise understanding of the context (Shelton, 2017). It is also claimed that a thorough geospatial analysis takes time (Crampton, 2015) and that it is encouraging to combine content analysis with "multidisciplinary collaborations" (Tsou, 2015). We argue that emergency- 
managers and decision-makers enthusiasm for volume and speed as acquired by SMEM overlooks such issues and can lead them to overrate real-time usability.

\section{Research design}

We used Twitter data from terror attacks in Paris (France), Nice (France) and Brussels (Belgium) from 2015 to 2016 to test such expectations. The precise time and space settings of terror attacks allow for a detailed comparison of the specific unfolding of events with the dissemination of information in space and over time on social media. The time (in minutes) can also be accurately tracked before an official alert is issued and the first crowdsourced information becomes available. The Paris attacks occurred on November $13^{\text {th }}$ 2015, with the Stade de France bombing at 21:17, the first street mass shootings at 21:20, and the Bataclan shootings at 21:40. The Brussels attacks took place on March $22^{\text {nd }} 2016$, with bombings at the Zaventem airport at 7:58 and at Maelbeek metro station at 9:11. The attack in Nice occurred on July $14^{\text {th }} 2016$, as a truck started to run over spectators of the National Day fireworks on the "Promenade des Anglais" at 22:30. In our framework (fig. 1), the Paris and Brussels attacks fall into the same category because they were both composed of multiple attacks at different places over several hours, while the Nice attack was a shorter and single event.

We used these three events to test expectations for real-time SMEM usability. In France, decisionmakers expect to have a better dissemination of early warnings and improved communication with citizens during emergencies ${ }^{2}$. At a local level, emergency-managers also expect improved warnings, awareness and data collection with SMEM; many have implemented Virtual Operations Support Teams (VOST) (Douvinet et al., 2017). In Belgium, a more comprehensive SMEM approach was implemented in 2013, including top-down early warnings, bottom-up participatory data collection, and a many-to-many approach ${ }^{3}$ : monitoring social media to detect first-hand information from the field during emergencies. We group these expectations in four assumptions often assumed to be true, and we add one final hypothesis derived from our framework:

1. Social media allow for a faster and more widespread dissemination of early warnings to the general population than conventional channels.

2. Social media foster bottom-up processes; they bring citizens closer to first-responders and decision-makers, and thus involve citizens in emergency management.

3. Geotagged information is useful to monitor the unfolding of a crisis in real time, to accurately detect events and map people, their expressed needs and actual behaviors.

4. Social media data offers richer, more complete and contextualized crowdsourced feedback than calls to emergency hotlines; such information is easily and rapidly accessible and processable in real time.

5. Emergency communication and SMEM usability is conditioned by local governance and geographical context.

The selected case studies are close in time and space, and are located in dense and developed cities where the case for social media is the most obvious. They are however in different national emergency management contexts while having varying degrees of political clout, multi-linguistic, and touristic backgrounds. The novelty of our approach is to use such a Belgium and France

2 The French Ministry of Interior partners with major actors to warn populations in case of an emergency, op. cit.

3The use of social media for communications by Belgian's crisis center. Practical guidance (November 2013) https://centredecrise.be/fr/publication/les-medias-sociaux-en-communication-de-crise 
comparison as well as our SMEM framework (fig. 1) to specifically test for the fifth hypothesis, which is least studied in the existing literature.

\section{Methods}

\subsection{Data scraping}

We built our datasets using the Twitter Intelligence Tool (Twint), an open-source python library dedicated to scrape Twitter's data. We chose this method rather than Twitter's API v1 because by the time of our dataset extraction, it was not possible to extract tweets that were published more than 7 days before the query time or only small samples ${ }^{4}$. Twint uses Twitter's operators to scrape specific requested data. The query has to be made by selecting either an account, a keyword or a location in a time period. The amount of collected tweets seems unlimited, allowing for the creation of larger datasets without limitation. Twint does not provide the retweets unless specified in the query. Yet, there are drawbacks to not using Twitter's API, as it implies not having access to the detailed latitude and longitude fields on the geotagged tweets. Twint only returns the city where the tweets were geolocated by the users. All datasets were restricted approximately 3 hours after each event in the case of multi-attacks.

\subsection{Keywords selection}

We extracted 3 datasets per attack, bringing on a total of 9 datasets. For each attack, we extracted one top-down, one bottom-up and one many-to-many dataset according to the three main SMEM uses (Latonero and Shklovski, 2011). These three flows of information and the three corresponding uses are acknowledged in the French agreement with Twitter, Facebook and Google (op. cit.) and detailed in the Belgium crisis center documentation (op. cit.). Top-down datasets collected the messages sent by the Twitter official accounts of local and national governments, first-responders, emergency managers, police, news and press. These datasets were used to test our first hypothesis on the speed and scope of early-warnings and our fifth hypothesis on the impact of local governance. Bottom-up datasets collected the tweets sent to the previously targeted official accounts (e.g. all tweets sent from the Belgian crisis center account were collected in the top-down dataset, whereas all tweets sent to or mentioning @CrisisCenterBe were collected in the bottom-up dataset). These datasets were used to test our second hypothesis on the involvement of the general public in emergency management. Many-to-many datasets collected all the tweets mentioning the 10 most recurrent keywords during the first 3 hours of each attack. Our queries were tested with plural forms (e.g. attack/attacks), different languages (English, Flemish and French), and collected all tweets with occurrences of the keywords (e.g. attacks) including hashtags (e.g. \#attack). Manyto-many datasets are thus broader and can include the tweets already collected in the top-down and bottom-up datasets. They were used to test all our hypotheses, including on geotagged information, richer content, and contextualized feedback.

\subsection{Mapping}

Based on our many-to-many datasets, we used the QBano QGIS plugin to place geotagged tweets on a map. This relates to our third hypothesis. We wanted to identify the proportion of tweets

\footnotetext{
4 Very recently, Twitter has released a Search API v2. With an academic account, it is now possible to overcome these constraints and theoretically to search the full archive. We have compared both approaches, Twint and Twitter API v2. While the two methods return confirmatory results both in volume and timing - validating our scraping approach Twint still collects up to $10 \%$ more tweets at any moment than the recently updated API.
} 
geotagged on-site, as opposed to geotagged in other parts of the country, in order to compare the overall spatial distribution with population density (Li et al., 2013) and with previous results that showed low geotagged rates (Graham et al., 2014). As on-site geotaged tweets are more likely to provide first-hand information, the overall geotagged rate alone is not sufficient to evaluate the usability of the information. We have also mapped the geotagged tweets rate per 10,000 inhabitants at the finest possible granularity.

\subsection{Timelines}

We investigated for each case study the detailed timelines of Twitter uses during the attacks. To test the reaction time during the terror attacks, we recorded the comprehensive timelines of relevant tweets. Starting at the hour before each event to detect the signal-to-noise ratio, we plotted the total amount of tweets for each keyword or account every five minutes, up to three hours after the attacks. For each case study, we reconstructed four timelines of tweets, one for the top-down, one for the bottom-up, one for many-to-many datasets, and one for the extraction of the geotagged tweets; this enabled us to compare the sequences and reaction times of the different uses. We also pinpointed the first tweet after the start of the events by officials, emergency responders accounts and by the press, both at the local and national levels, to accurately measure the time lag between each event and the first related warning on social media.

\subsection{Finding needles in a haystack}

We used the many-to-many datasets to test our first and fourth hypotheses. Unlike ex post facto retrospective analyses (Cheng et al., 2016), we decided not to use algorithms to look for needles in a haystack to be closer to the real crisis conditions because emergency managers are not using algorithms for harvesting information yet (Santoni and Audoin, 2017).

From a SMEM perspective, useful information has to be available, first-hand, on site, geotagged, properly referenced with the event's specific keyword, published within a short period of time, and before first-responders arrive on site (Albuquerque et al., 2015; Douvinet et al., 2017; Rive et al., 2012; Saldana-Perez et al., 2019). We extracted subsets spanning 15 minutes before and 15 minutes after each event. Such a 15 minutes time interval reflects the average time first-responders take to reach an emergency situation ${ }^{5}$. We also extracted the 15 minutes before the events to check the signal to background noise ratio.

For each subset, we manually checked the proportion of tweets that truly related to the event. We recorded the time lag by calculating the delay between the start of each event and the very first related tweet. We also extracted geotagged tweets, tweets with pictures and videos, and calculated the delay before the first picture or video of the event was published. We separated tweets requesting information and those referring to the news and press from the tweets offering first-hand information, to test our first and fourth hypotheses.

5 French Fire and Emergency Departmental service, 2018 official stats https://www.interieur.gouv.fr/Publications/Statistiques/Securite-civile/2018 


\section{Results}

\subsection{Keywords}

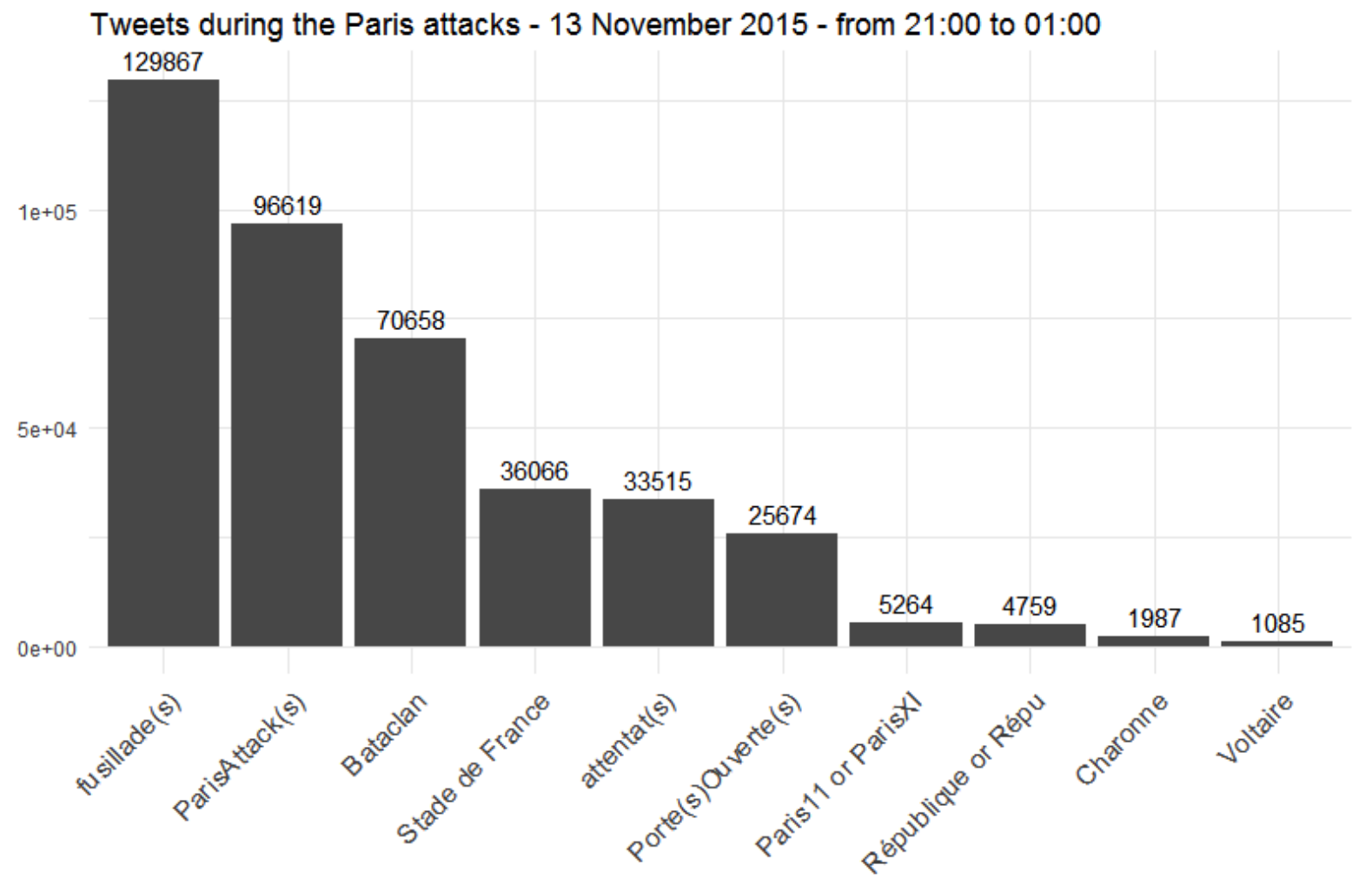

Fig.2 Top 10 Twitter keywords during the Paris attacks in November 2015

During the Paris attacks (fig.2), top keywords first refer to the ongoing events, and second to their location. We aggregated the singular and plural forms of shooting(s) ("fusillade(s)") and terror attack(s) ("attentat(s)"). The terms refer to the attacks at the concert hall ("Bataclan", starting at 21:40), in the streets ("Voltaire"), plazas ("République") and subway stations ("Charonne") in Paris $11^{\text {th }}$ district ("Paris11") where the mass shootings started at 21:20. The explosion at the national stadium ("Stade de France", north of Paris) occurred at 21:17, twenty minutes after the start of the game. We also aggregated diminutives ("Répu") and variants ("ParisXI"). "Porte(s)Ouverte(s)" (“open doors" singular and plural) refers to the keywords used by Parisians to provide shelter to those afraid to travel back home after the attacks. 
Santoni, V., \& Rufat, S. (2021). How fast is fast enough? Twitter usability during emergencies. Geoforum, 124, $20-35$.

Tweets during the Brussels attacks - 22 March 2016 - from 7:30 to 12:00

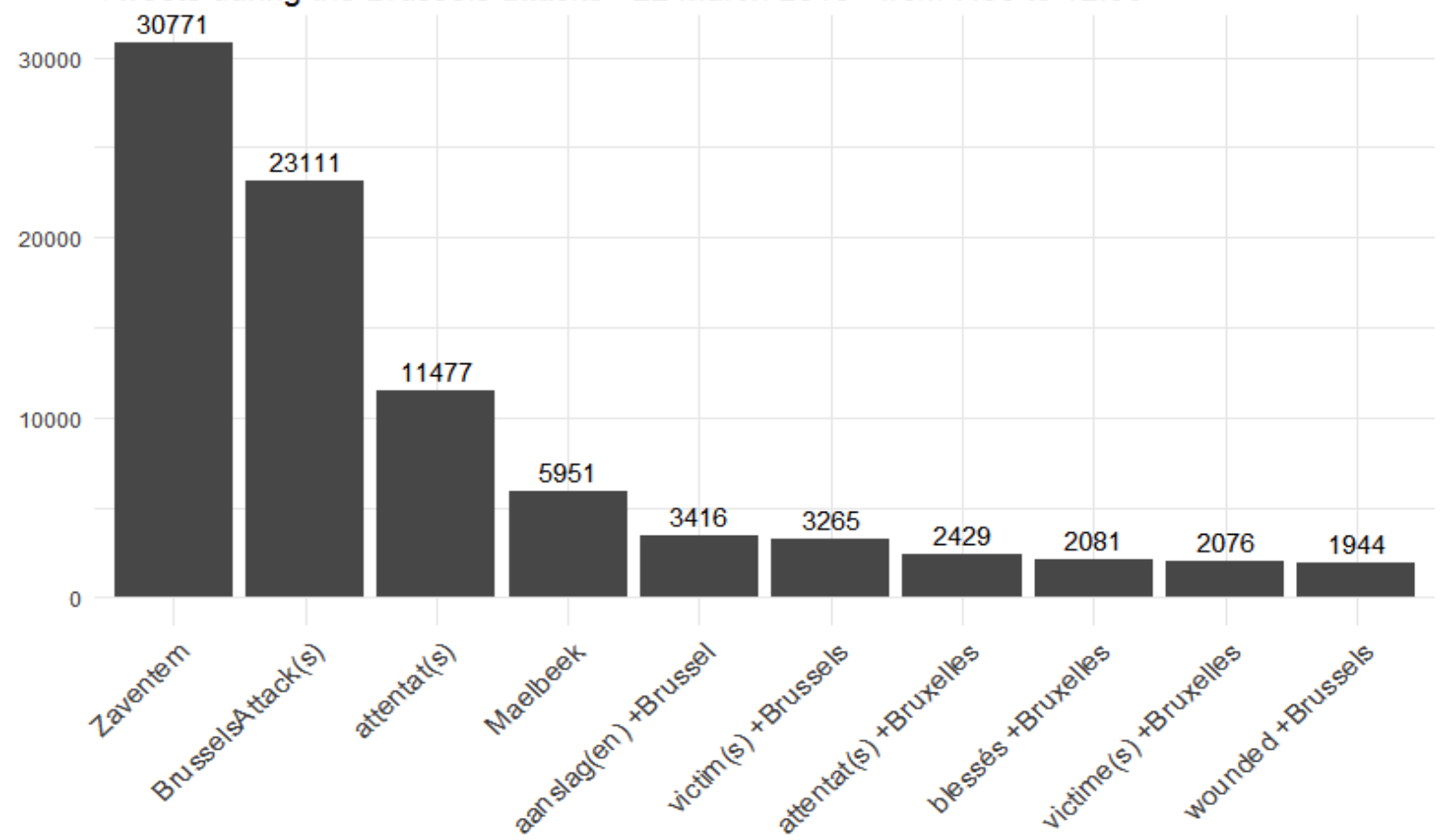

Fig.3 Top 10 Twitter keywords during the Brussels attacks in March 2016

During the Brussels attacks (fig.3), the main keyword refers to the international airport ("Zaventem") bombed at 7:58. "Maelbeek" is the subway station where the second explosion occurred at 9:11. We aggregated the singular and plural forms of several variants of terror attacks in English, Flemish and French, with or without the location ("BrusselsAttack(s)", "attentat(s)", "aanslag(en) + Brussel", "attentat(s) + Bruxelles"). The other keywords are "victims" ("victimes") and "wounded" ("blessés") in English and French when associated to Brussels. 


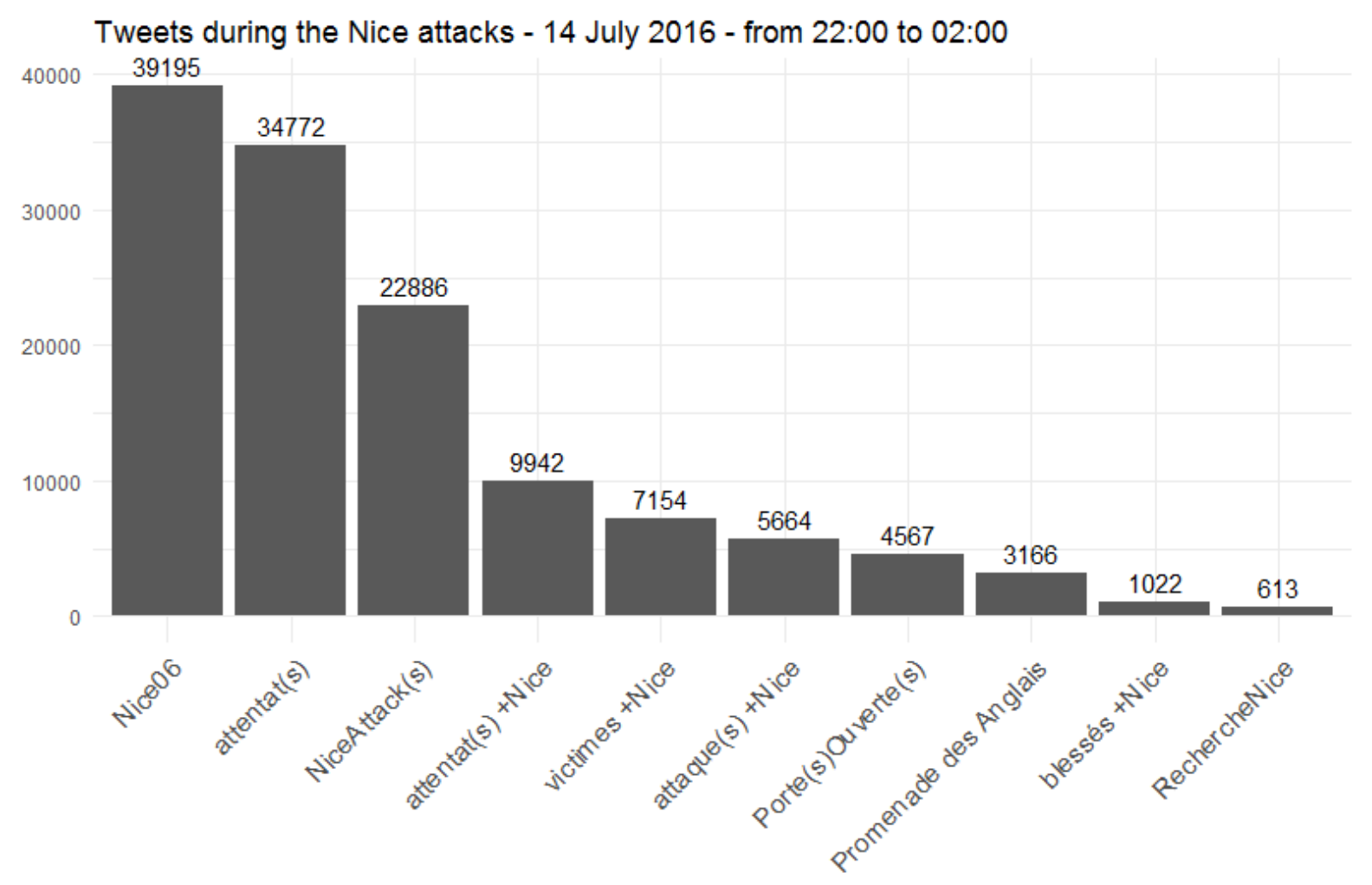

Fig.4 Top 10 Twitter keywords during the Nice, France attacks in July 2016

During the attack in Nice, France (fig.4), the city's name was difficult to use, as "nice" is a popular English word. It is commonly associated to the number of the French Riviera department as a hashtag (\#Nice06). The only other location name in the top 10 keywords was Promenade des Anglais on the waterfront, where the attack started around 22:30. We aggregated the singular and plural forms of several variants of terror attacks, with or without the location ("attentat(s)", "NiceAttack(s)", "attentat(s) +Nice”, "attaque(s) +Nice”). The other keywords are "victims" ("victimes") and "wounded" ("blessés") in French when associated to Nice, the variants of "open doors" ("Porte(s)Ouverte(s)"), as well as the keyword used by people seeking news of their relatives ("RechercheNice"). 


\subsection{Geotagged tweets}

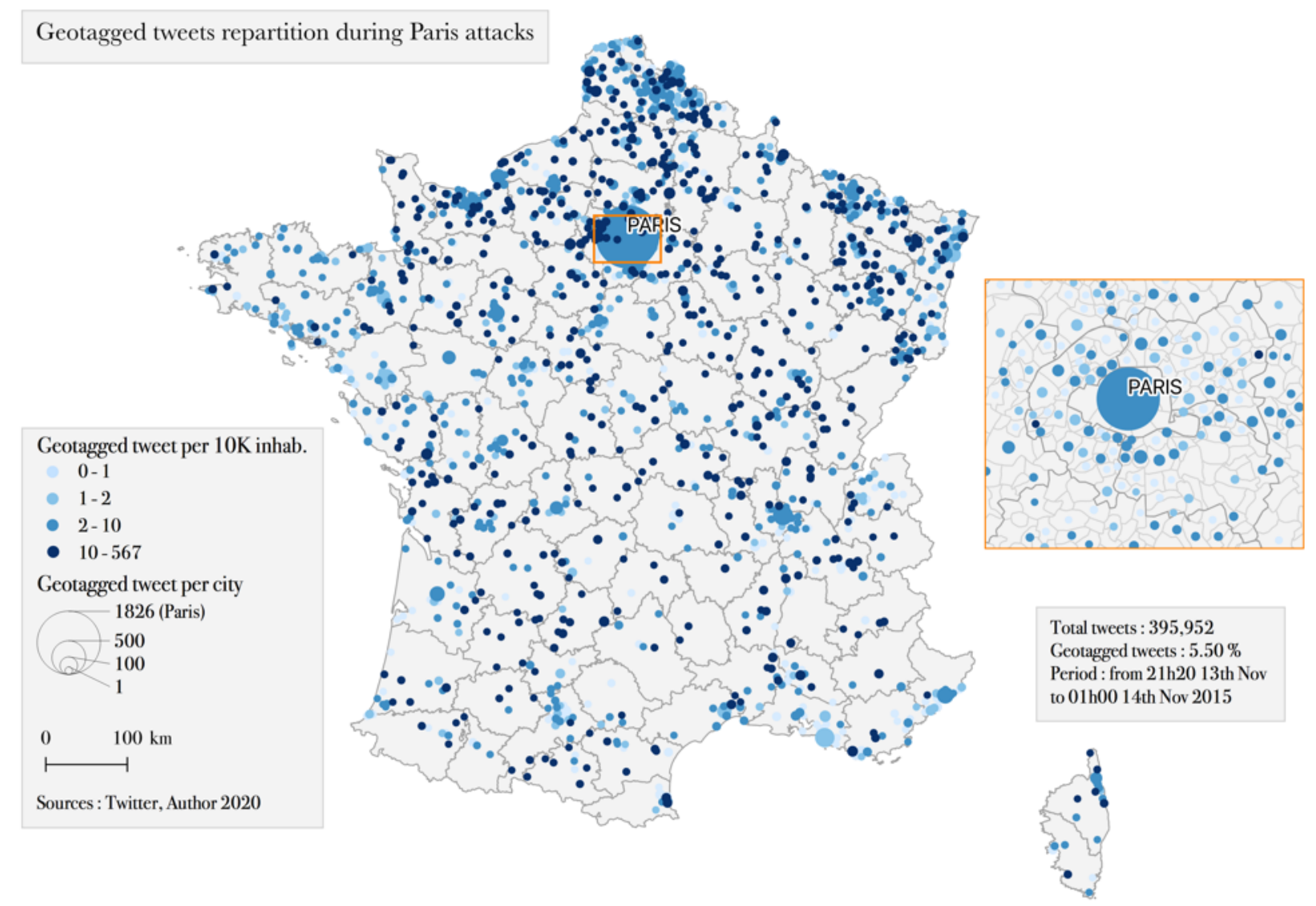

Fig.5 Geotagged tweets distribution during the Paris attack

In Paris, geotweets represented 5.5\% of the Paris sample, but only $0.5 \%$ (1,826 tweets) were located in the Paris area in the three hours that followed the attacks (fig.5). Tweets geotagged within Paris represented $18 \%$ of the French geotweets sample, while the Parisian population represented $4 \%$ of the total French population. There were irregularities regarding the geotweets to population ratio as some medium-sized cities (Reims, Saint Etienne, Grenoble, Dijon) did not well, while cities like Villejuif (51 geotweets for 56,661 inhabitants) and Creutzwald (46 geotweets for 13,255 inhabitants) were well represented. 


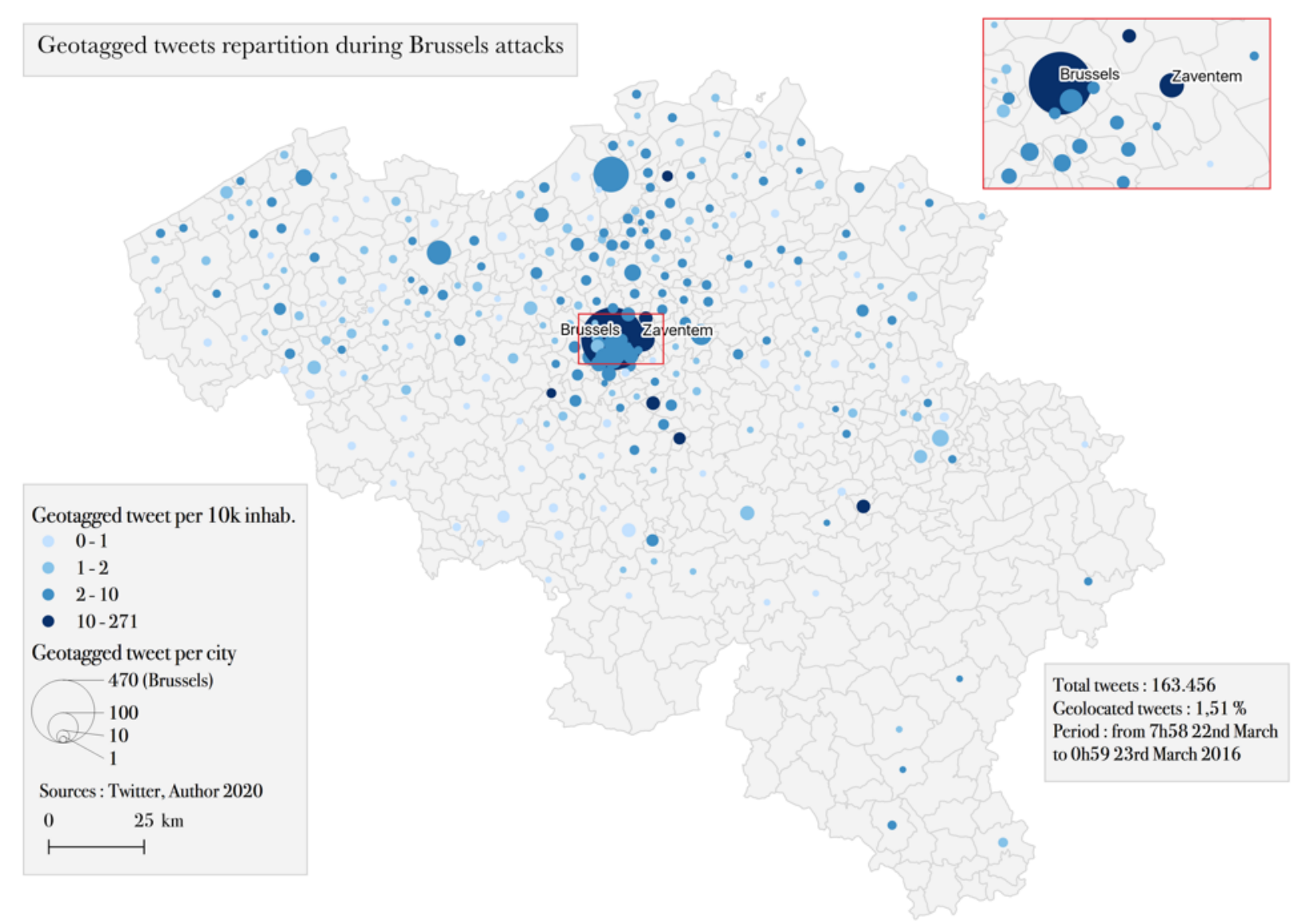

Fig.6 Geotagged tweets distribution during the Brussels attack

In Brussels, geotweets represented 5.3\% of the Brussels sample, but only $0.3 \%$ (227 tweets in Brussels and 24 tweets in Zaventem) were located in the area in the three hours that followed the attacks (fig.6). Geotweets within the Brussels area represented 36\% of the Belgium events geotweets while Brussels population accounted for $10 \%$ of the total Belgium population, which reveals the spatial effect of the event. There was a major contrast between the French-speaking regions in the South (only 12\% of the geotweets) and the Flemish-speaking regions in the North (52\% of all Belgian geotweets). 


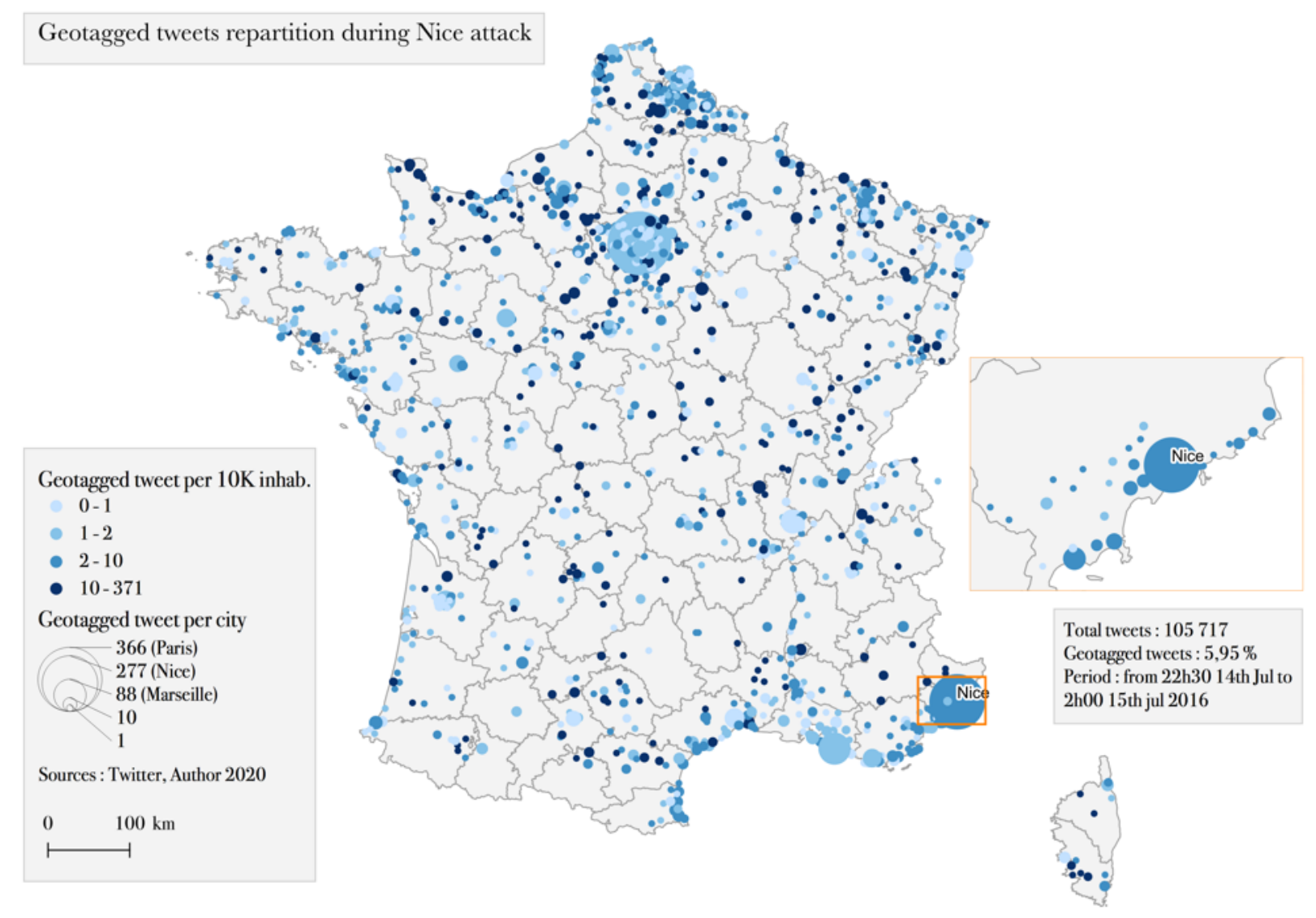

Fig.7 Geotagged tweets distribution during the Nice attack

In Nice, geotagged tweets represented $6.1 \%$ of the Nice sample, but only $0.3 \%$ (291 tweets) were located in Nice during the three hours following the attack (fig.7). Geotweets within Nice represented $7 \%$ of the Nice events geotweets sample while Nice population accounted for $1.4 \%$ of the total French population. Paris municipality is still the first geotagged city (405 geotweets), almost at a tie with the entire Nice area (438 geotweets) but with twice as many inhabitants (2.2 million inhabitants in Paris vs. 1.1 million inhabitants in the Nice area). Southern cities in the Nice and Marseille areas were well represented. 
Santoni, V., \& Rufat, S. (2021). How fast is fast enough? Twitter usability during emergencies. Geoforum, 124, $20-35$.

\subsection{Timelines}

For every event in all three case studies, warnings from official accounts were sent one to two hours after the attacks had started (fig.8). The press systematically had a much quicker reaction time. Overall, the peak of tweets related to the event occurred before the official alert. Delays were shorter for the events that followed the first attack, and they were generally shorter in Belgium than in France.

\begin{tabular}{|l|l|l|l|}
\hline \multicolumn{1}{|c|}{ Event (case study) } & $\begin{array}{c}\text { First tweet from the press } \\
\text { (delay in minutes) }\end{array}$ & $\begin{array}{c}\text { Peak of tweets when col- } \\
\text { lating all keywords }\end{array}$ & $\begin{array}{c}\text { First tweet from an official ac- } \\
\text { count }\end{array}$ \\
\hline Stade de France (Paris) & 53 & 115 & 118 \\
\hline Paris street shootings & 31 & 110 & 115 \\
\hline Bataclan (Paris) & 62 & 90 & 95 \\
\hline Zaventem (Brussels) & 20 & 60 & 70 \\
\hline Maelbeek (Brussels) & 17 & 50 & 54 \\
\hline Attack in Nice & 30 & 75 & 79 \\
\hline
\end{tabular}

Fig.8 Delays between the attacks and tweets mentioning them for each event

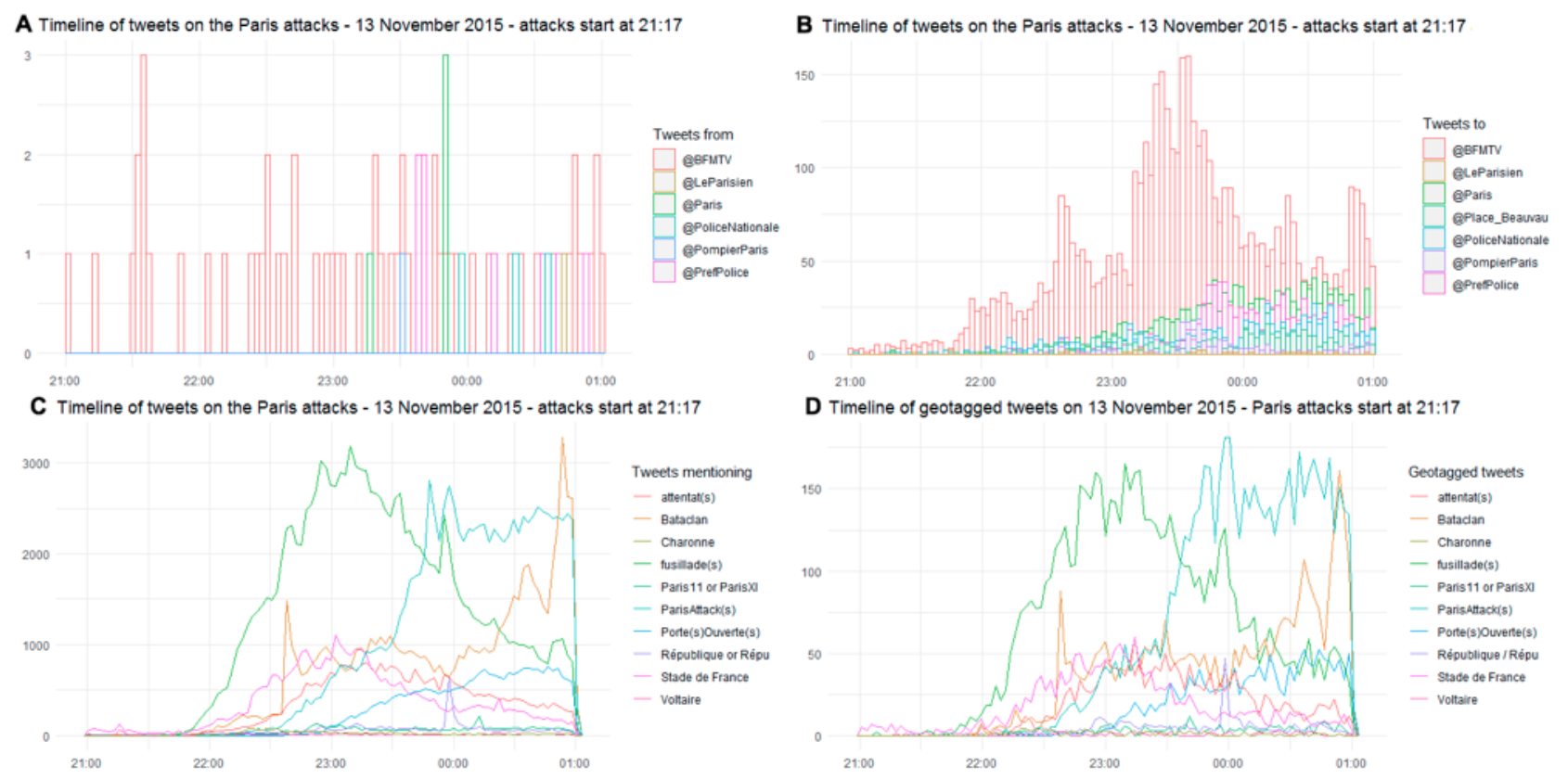

Fig.9 Timeline of tweets during the Paris attacks in November 2015

In Paris, the first tweet from an official account occurred at 23:15 and was made by the Municipality of Paris (@Paris), urging people to stay indoors and to wait for further official instructions (fig.9A). The only tweet from first-responders (@PompiersParis) was made later, at 23:29, to warn that their emergency hotlines were flooded by distress calls. The only tweet from the police (@PoliceNationale) was to ask people to stop spreading rumors, at 23:58. It was later translated in English and German, but still they did not raise the alarm. The 24-hours news TV (@BFMTV) did raise the alarm at 21:50, informing of several shootings in the streets of Paris, then 
of the explosion at the stadium at 22:10, and later of the attack on the Bataclan concert hall at 22:42. The tweeting pattern remained the same before and after the attacks, making it difficult to spot the dramatic events without content analysis. The local press (@LeParisien) did not tweet until after midnight. Many official accounts, such as the one of the French Ministry of Internal Affairs known by the name of its address in Paris @Place_Beauvau - did not tweet that night.

The same is true for bottom-up tweets (fig.9B): users were much more engaging with the press than first-responders, local authorities or the police. Overwhelmingly, these tweets requested more information, some shared substance with official accounts, and a minority were conversational (replies, retweets, etc.). However, almost all questions and attempts to interact remained unanswered. Only after the alarming tweets from the press - first around 22:00 and then after 22:40 - did the tweeting pattern began to change, making an unusual situation visible.

Overall, locations (e.g. "Stade de France") were mentioned both before and after the events (fig.9C), making it difficult to detect an irregularity before their occurrence quickly soared, especially as regards to the Bataclan after 22:40 - i.e. after it was explicitly mentioned in the press. Similarly, the steady increase in the occurrence of the term "shootings" ("fusillade(s)") started once it had been mentioned in the press. The peak of tweets mentioning the top 10 keywords occurred around 23:10, almost two hours after the start of the attacks but before the first official tweets. As the evening progressed, the bulk of the tweet volume moved from generic keywords (shootings, attacks, etc.) to specific locations (Voltaire, Charonne, etc.), from mostly French to a growing use of English (\#ParisAttack(s)), and from a description of events to offers of help ("open doors", \#PortesOuvertes).

Extracting only geotagged tweets $(5.5 \%)$ did not alter the sequence and pattern of the timeline (fig.9D). Because it dealt with smaller volumes, it was easier to see the "noise" before the events and the very few tweets mentioning shootings in Paris before the press raised the alarm at 21:50.

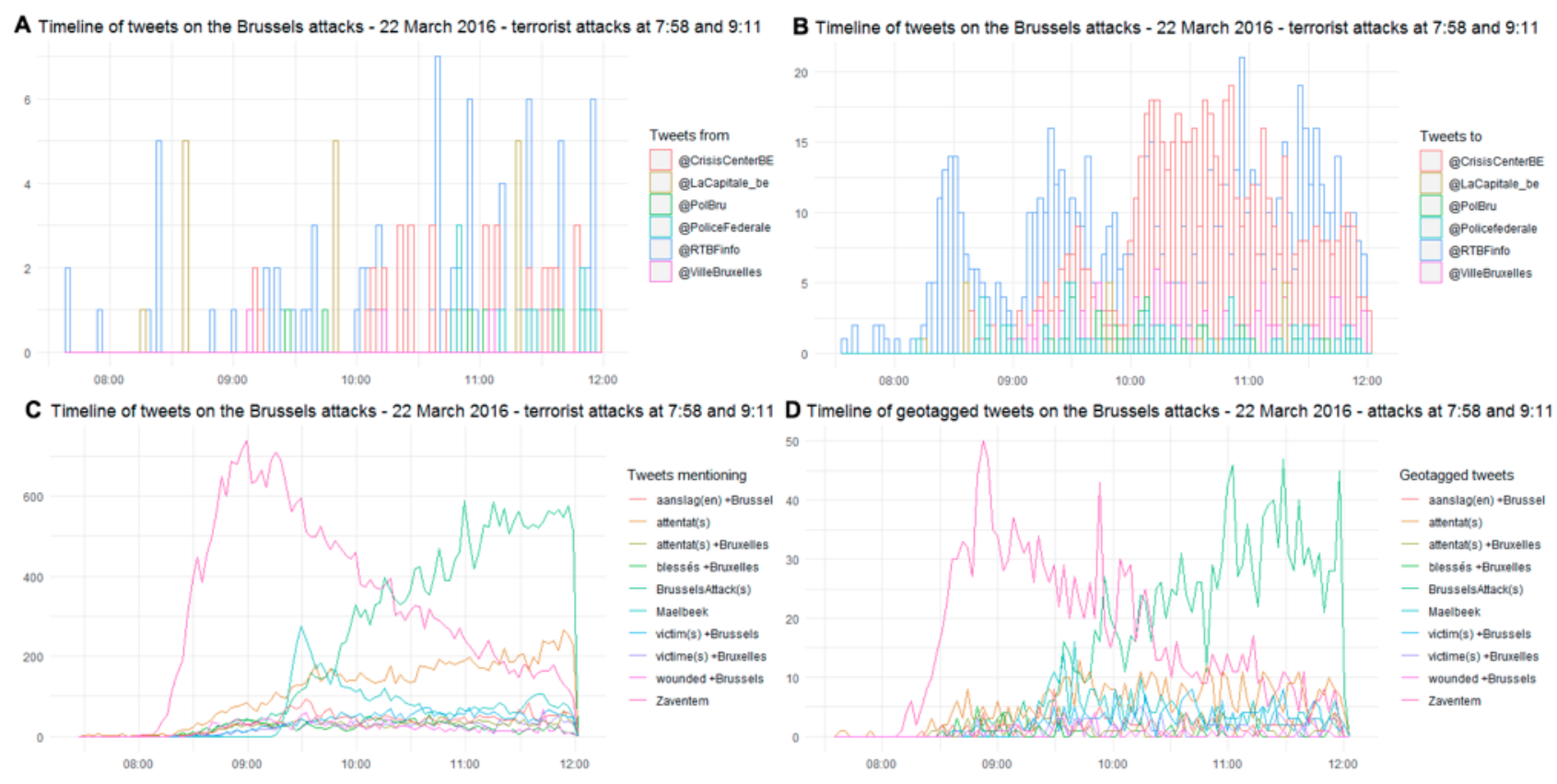

Fig.10 Timeline of tweets during the Brussels attacks in March 2016

In Brussels, the first tweet from an official account to raise the alarm was sent by the municipality at 9:08 (@VilleBruxelles), and at 9:09 by the national crisis center (@CrisisCenterBe) (fig.10A). After the 9:11 explosion at the Maelbeek subway station, @CrisisCenterBe announced the 
interruption of all public transport services at 10:05 in different languages, but still in reference to the Zaventem events. At 10:21, it informed of the saturation of the emergency hotlines in three languages: "Don't call. Use texting or social media. Network is getting saturated \#Brussels". Only after 11:36 did the official accounts start mentioning the surroundings, but the subway station and the explosion were not officially specified until the afternoon. The national TV (@RTBFinfo) tweeted the first explosion at Zaventem at 8:18 and located the second one at the Maelbeek station at 9:28. The local press (@LaCapitale_be) was slower - at 8:35 and 9:48 respectively. The media tweeting pattern slightly changed around 8:30, with a sudden greater volume of publication, making it easier to detect the dramatic situation.

At first, users shared information, testimonies and information requests substantially more with the press than with first-responders (fig.10B). Interactions with the local authorities and the police started to appear around 9:00, and the national crisis center quickly took over afterwards. After 10:00, the majority of tweets were inquiries, requests for more detailed information, replies, etc., and the various accounts failed to publish enough tweets to cope with all these interactions.

The name of Zaventem airport started to emerge moments before the location of the explosion was mentioned in the press (fig.10C). The name of Maelbeek station was also introduced right before the press disclosed it. There remained a 15 to 20 additional minutes delay before the volume was large enough to detect an unusual event. The qualification of the events only arose after further delay and in much smaller volumes. Some of them were already used before the events for unrelated comments, making it challenging at first to separate signal from noise. The peak of tweets occurred before the first official accounts raised the alarm.

Extracting only geotagged tweets (5.3\%) did not alter the timeline (fig.10D). Reaction delays, however, seemed slightly longer during the first half hour after each event.

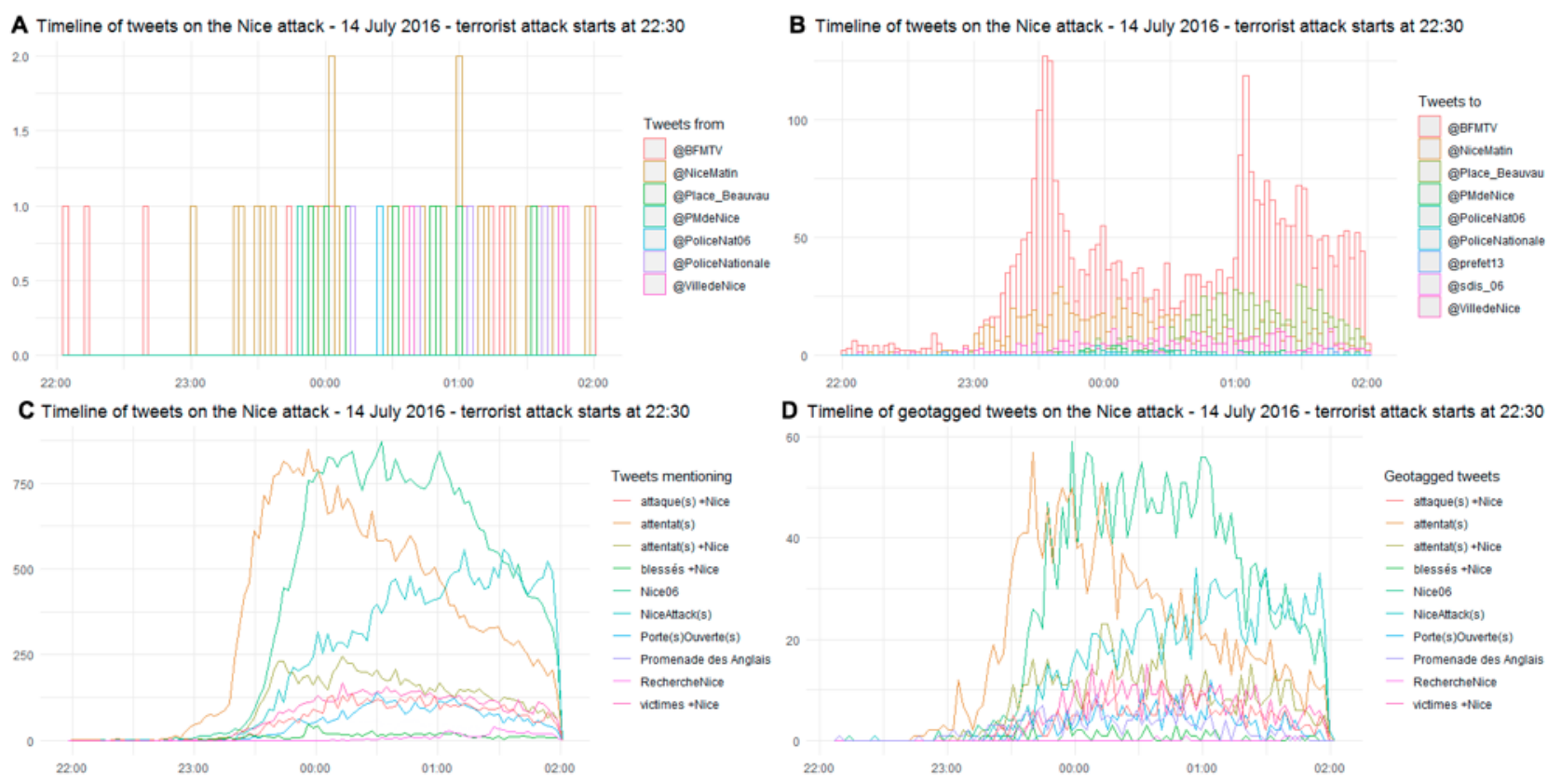

Fig.11 Timeline of tweets during the Nice, France attacks in July 2016

In Nice, the first tweet from an official account was published at 23:49 by the local police (@PMdeNice) (fig.11A). The message in French was to stay inside because of ongoing police operations. Only after 00:37 did official accounts begin to mention the term "attack" and the location, mostly to counter rumors of a hostage situation. The local press (@NiceMatin) disclosed 
the attack and location at 23:00, and the TV (@BFMTV) tweeted breaking news at 23:43. The tweeting pattern remained the same before and after the attacks. Many official Tweeter accounts, such as that of local first-responders (@sdis_06) or the regional crisis center (@pref13), did not tweet that night.

Here again, users first interacted much more with the press than with first-responders (fig.11B). The first peak followed the first tweet from the local press, asking what was going on in Nice, and the second stemmed from outrage over media coverage and/or police's request not to disseminate images or information. Though initially very low, interactions with first responders increased throughout the night and official accounts failed to publish enough tweets to even cope with genuine questions, information feedbacks or expressions of support.

The reaction time of users during the Nice, France attacks (fig.11C) placed them right before the local press (23:00), although the increase became considerable an additional 15 minutes afterwards. The timeline first swelled with the qualification of the events; location keywords appeared later ("Promenade des Anglais"). Tweets were increasingly published in reaction to the press breaking news and coverage rather than to share first-hand information. The peak of tweets occurred before the official accounts raised the alarm. Only later in the night did tweets deal with offering help ("Porte(s)Ouverte(s)") or inquiring about relatives ("RechercheNice”) rose.

Extracting only geotagged tweets (6\%) did not alter the timeline (fig.11D). It facilitated the spotting of the first mentions of the events, even if the volumes remained extremely low before the first tweet from the press at 23:00.

\subsection{Finding needles in haystack}

\begin{tabular}{|c|c|c|c|c|c|c|c|c|c|c|c|c|}
\hline Event & $\begin{array}{l}\text { Total } \\
\text { tweet }\end{array}$ & $\begin{array}{c}\text { Related } \\
\text { tweet }\end{array}$ & $\begin{array}{l}\% \text { Re- } \\
\text { lated }\end{array}$ & $\begin{array}{l}\text { Time } \\
\text { lag } \\
\text { (min) }\end{array}$ & $\begin{array}{c}\text { Geo } \\
\text { tagged }\end{array}$ & $\begin{array}{l}\text { Picture } \\
\text { / Video }\end{array}$ & $\begin{array}{c}\text { Pic lag } \\
\text { (min) }\end{array}$ & $\begin{array}{l}\text { Refer- } \\
\text { ring to } \\
\text { press }\end{array}$ & $\begin{array}{l}\text { Re- } \\
\text { quest } \\
\text { info }\end{array}$ & $\begin{array}{l}\text { 1st- } \\
\text { hand } \\
\text { info }\end{array}$ & $\begin{array}{c}\text { 1st- } \\
\text { hand } \\
\text { account }\end{array}$ & $\begin{array}{l}\% \text { 1st- } \\
\text { hand }\end{array}$ \\
\hline $\begin{array}{l}\text { Stade de } \\
\text { France }\end{array}$ & 865 & 29 & 3,4 & 1 & 0 & 0 & 0 & 1 & 5 & 16 & 15 & 1,8 \\
\hline Shooting & 788 & 24 & 3,0 & 8 & 6 & 5 & 1 & 1 & 5 & 16 & 10 & 2,0 \\
\hline Bataclan & 1317 & 17 & 1,3 & 9 & 0 & 0 & 0 & 0 & 3 & 4 & 3 & 0,3 \\
\hline Zaventem & 82 & 43 & 52,4 & 3 & 3 & 2 & 3 & 8 & 14 & 17 & 12 & 20,7 \\
\hline Maalbeek & 10180 & 632 & 6,2 & 4 & 33 & 41 & 8 & 166 & 52 & 9 & 9 & 0,1 \\
\hline Nice & 30 & 8 & 26,7 & 7 & 1 & 0 & 0 & 2 & 2 & 3 & 3 & 10,0 \\
\hline
\end{tabular}

Fig.12 Overall reaction time during the first 15 minutes.

The time lag for first-hand information is below 10 minutes but only returned consequences of the attack, which implies that there was no direct visual testimony (Fig. 12). To the exception of Zaventem and Nice, first-hand information represents less than $2 \%$ of the whole information. Unless it was published by a journalist, first hand-information was not easily accessible because users did not necessarily use hashtags or understood what was happening. This was different in the case of multi-events, as information from previous events increased the noise. In the Stade de France attack, there was some confusion between people tweeting in-situ and people tweeting from their home, the game being broadcasted live, which explains why there were very few tweets about the on-site situation. Moreover, the explosions occurred just outside the stadium, which explains 
why it was not easy for people in the stands to apprehend the situation. During the shootings that took place in the $10^{\text {th }}$ and $11^{\text {th }}$ arrondissements, locals published the first tweets three minutes after the events had begun. The rare pictures taken after the shooting that took place at Le Carillon came from the user@pierre75010 who took photos of the restaurant from his window, or from the user @VinBerth, a journalist from BFM $\mathrm{TV}^{6}$ (fig.13). Police already appeared on the second photograph.
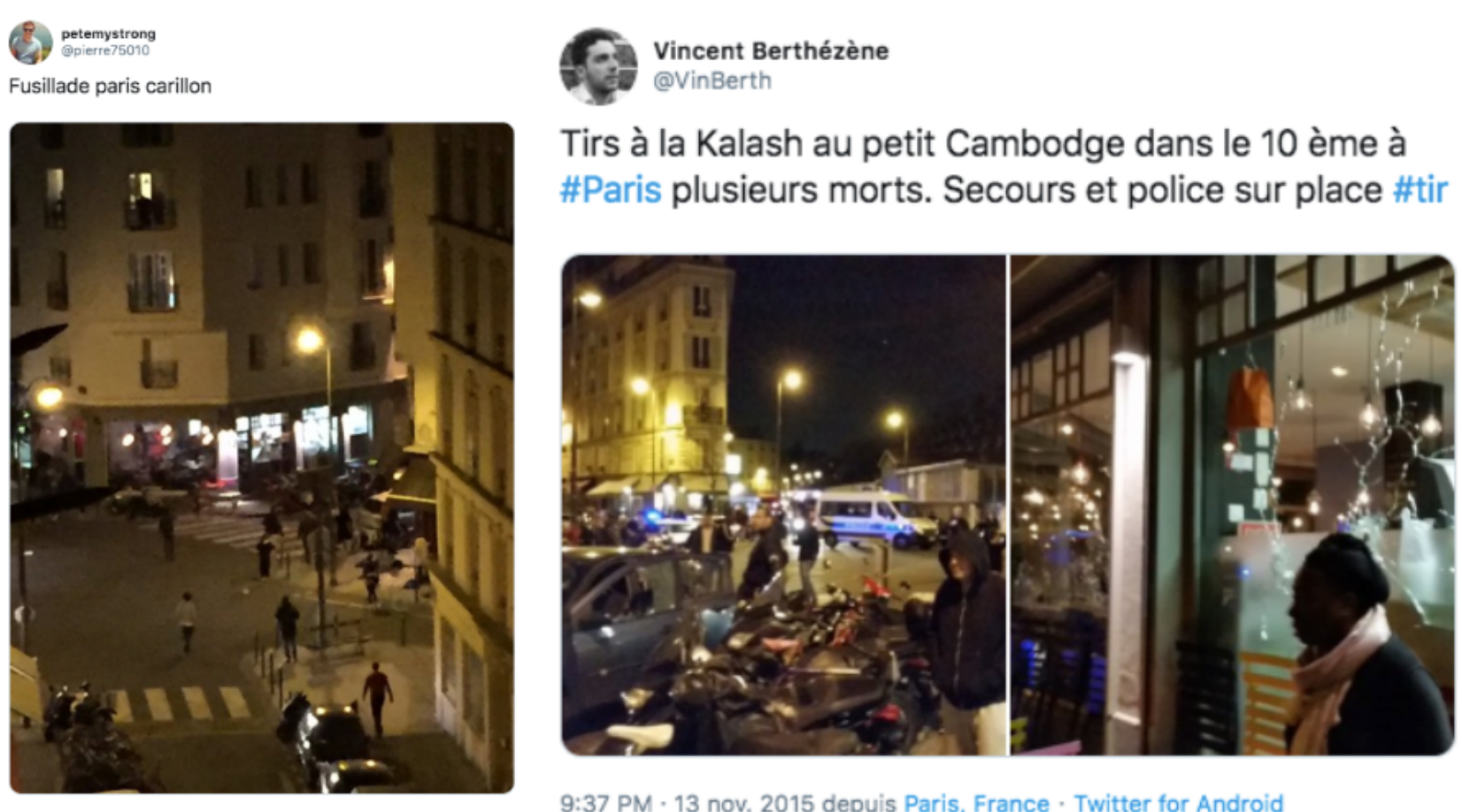

9:37 PM - 13 nov. 2015 depuis Paris, France - Twitter for Android

Fig. 13 Early pictures after the Paris shooting on Twitter ${ }^{7}$

The Bataclan shooting happened inside a building. The only tweets we have regarding the Bataclan were made by people who were hearing gunshots from the outside and by people who were escaping the building. Concerning the Zaventem bombing, the firsts tweets were published three minutes after the explosion from passengers explaining that there had been an explosion in the airport (fig.14) and users immediately tagged the media (\#vtmnieuws, @rtlinfo, @BFMTV, @ RTBFinfo). In this case, the approach was different, as users were not trying to gather news but rather to alert others. The first picture of the event was taken from inside the airport train station, three minutes after the blast, but the user did not have any information about what was happening (fig.15). Moreover, this picture is embedded in a tweet that does not have any of the keywords from our many-to-many datasets. We only discovered it because it was subsequently shared by another user who had used the keywords in our queries. A journalist in the parking lot outside the airport took the second picture. The information is qualified, referenced with fact, hashtags and highlighted with the "BREAKING" announcement (fig.15).

6 BFM TV is a French 24-hour rolling news channel.

$71^{\text {st }}$ tweet: "Shooting at the Carillon"

$2^{\text {nd }}$ tweet: "Kalashnikov fire in the Petit Cambodge in the $10^{\text {th }}$ in \#Paris many dead. Paramedics and Police on-site \#shot 
Santoni, V., \& Rufat, S. (2021). How fast is fast enough? Twitter usability during emergencies. Geoforum, 124, $20-35$.

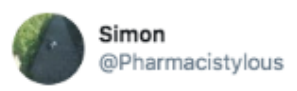

Twee \#explosies \#luchthaven \#zaventem \#vtmnieuws \#vrt

8:01 AM · 22 mars $2016 \cdot$ Twitter for Android
Arnauld Ibabila

@arnauldibabs

@rtlinfo @BFMTV @RTBFinfo \#zaventem attentat a bruxelles airport \#belgium attack

8:09 AM - 22 mars 2016 - Twitter Web Client

Fig. 14 During the Zaventem attack, the media were made aware of the explosion 3 minutes after it occurred $^{8}$

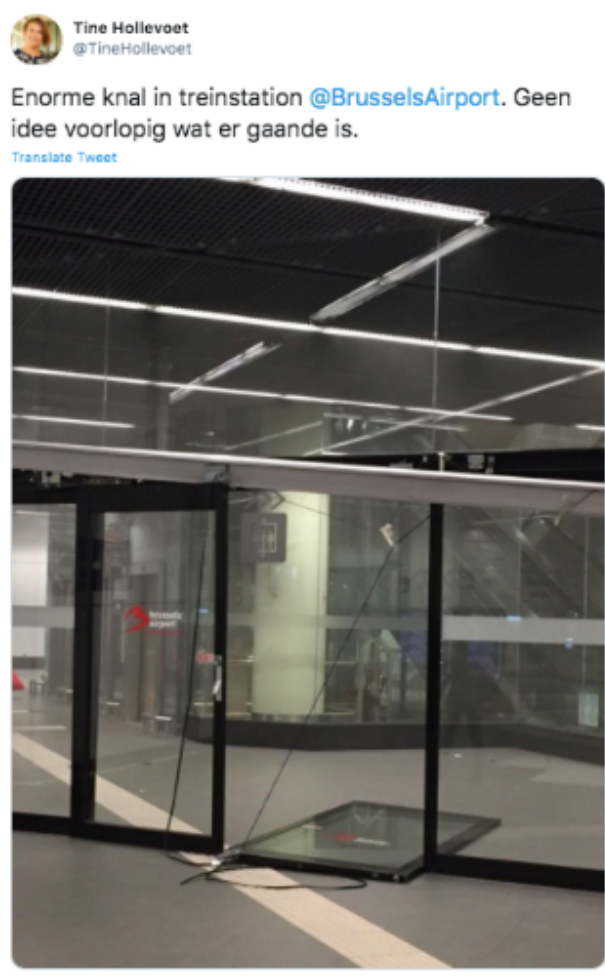

8:01 AM - Mar 22, 2016 - Twitter for iphone

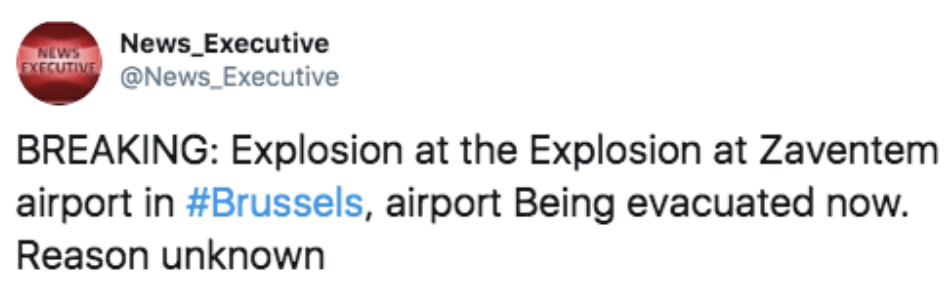

Traduire le Tweet

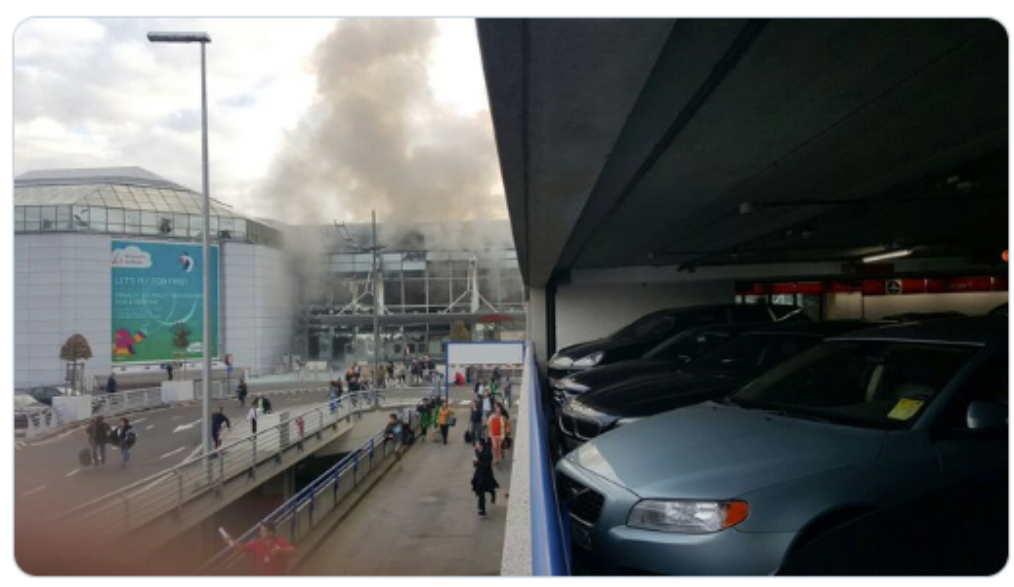

8:11 AM - 22 mars $2016 \cdot$ Twitter for BlackBerry

Fig. 15 Early pictures of the Zaventem attack on Twitter ${ }^{9}$

The Maelbeek dataset is filled with information about Zaventem because the two events took place in a short period of time. The first tweet came from a subway passenger who did not understand what was happening, the traffic having just been interrupted. Figure 16 shows that the journalist arrived on the scene eight minutes after the detonation, using the hashtag "Brussels". The second tweet shows a police patrol arriving on site ten minutes after the explosion.

\footnotetext{
$81^{\text {st }}$ tweet: "Two \#explosions \#airvents \#Zaventem \#vtmniews \#vrt"

$2^{\text {nd }}$ tweet: “@rtlinfo@BFMTV@RTBFinfo \#zaventem Brussels airport attack \#belgium attack”

$91^{\text {st }}$ tweet: "Huge explosion in the @BrusselsAirport train station. We don't know yet what's going on"
} 
Santoni, V., \& Rufat, S. (2021). How fast is fast enough? Twitter usability during emergencies. Geoforum, 124, $20-35$.
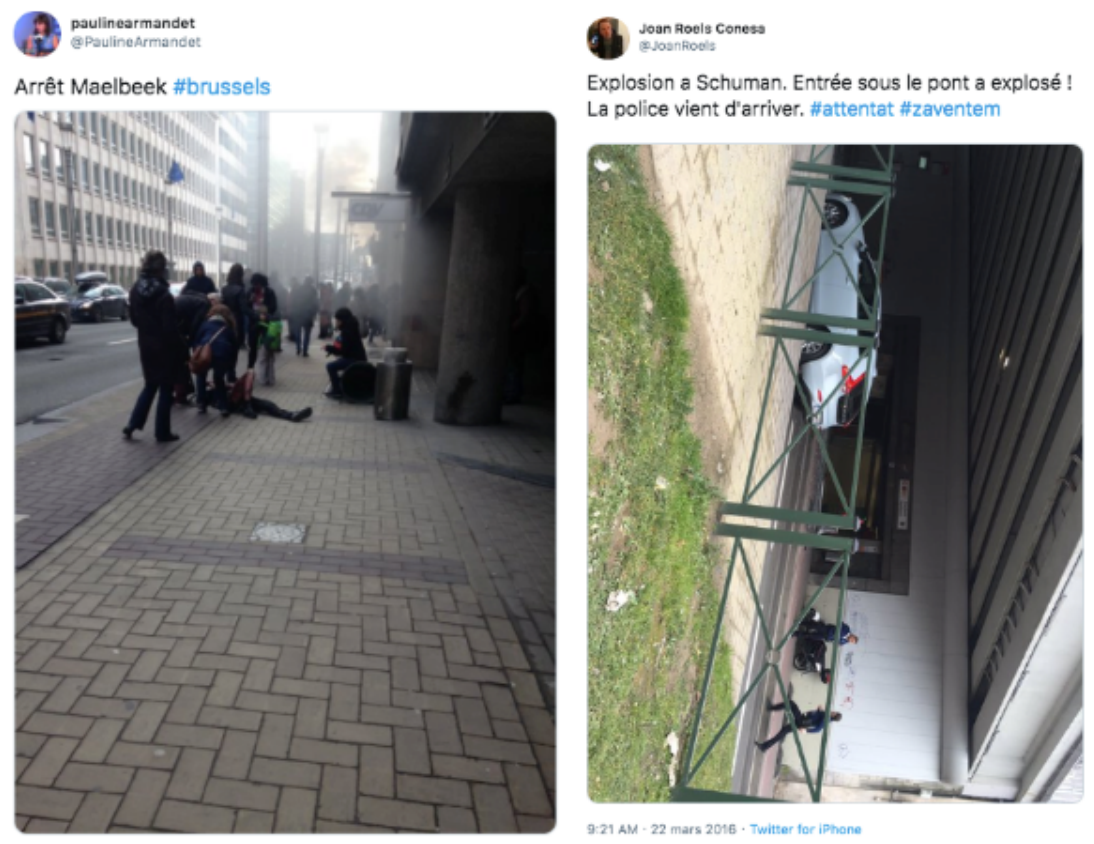

9:19 AM- 22 mars 2016 - Twitter for iphone

9:21 AM- 22 mars 2016 - Twiter tor iphone

Fig. 16 Early pictures and video of the Maelbeek event ${ }^{10}$

With the Nice attacks, the first tweet was written 13 minutes after the attack, asking the local media @ Nice_Matin if they had any information regarding an attack. We did not find a tweet that provided evidence of the attack in the first fifteen minutes, but we detected a video published in that time frame on Twitter that did not appear in our dataset (fig.17). The video shows people running from the attack area. We checked and found that our keyword research had not uncovered this video because the text message did not match any of our keywords, in fact the user seems to have a difficult time understanding the seriousness of the situation.

$101^{\text {st }}$ tweet: "Explosion in Schuman. The under the bridge entrance exploded! Police just arrived \#attack \#zaventem" $2^{\text {nd }}$ tweet: “@Dominique_Rizet Explosion in Arts-loi, Maelbeek (Belgium government) and Shuman (EU) stations” 


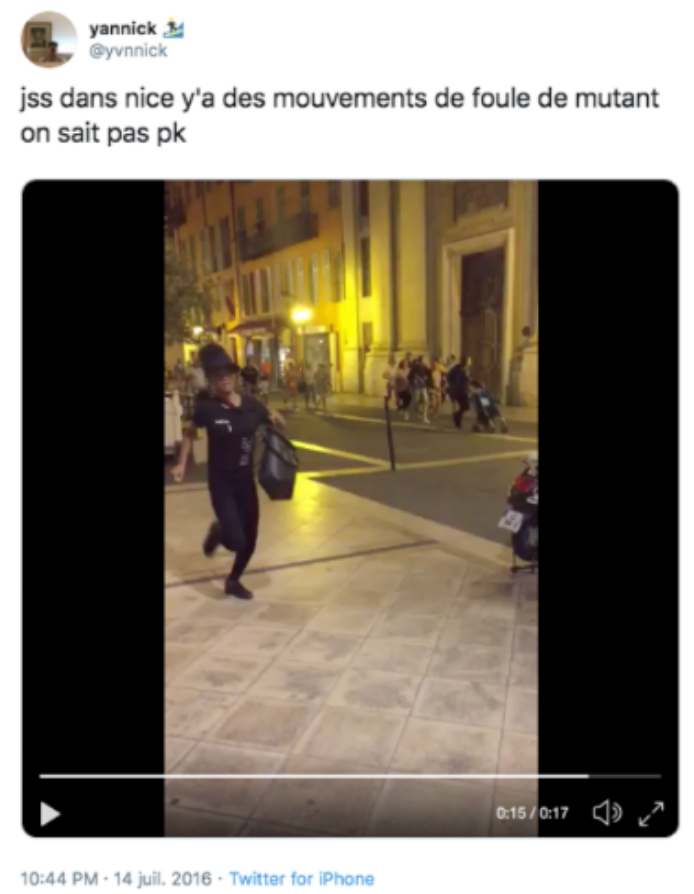

Fig. 17 People fleeing in an early video during the Nice $\operatorname{attack}^{11}$

\section{Discussion}

We have found that only $5 \%$ to $6 \%$ of tweets are geotagged, depending on the event. This represents however some of the highest rate of geotagged tweets reported in the literature (Graham et al., 2014; Takhteyev et al., 2012; Tsou \& Leitner, 2013). The strong correlation between geotweets and population density previously reported in the literature ( $\mathrm{Li}$ et al., 2013) does not fully explain the spatial distribution of geotweets. A social analysis of social media users might help understand such a distribution and the differences in proportions of relevant tweets to noise (Crutcher and Zook, 2009). Such an approach would however stumble on the various biases previously highlighted. Mixing quantitative and qualitative approaches provided better insight on what was happening on the ground, corroborating previous studies (Shelton et al., 2014; Tsou and Leitner, 2013). Choosing Twint over the Twitter API enabled to gather vast tweets datasets for each three-hour time slot, as could have been done in real-time during the events. As such, Twitter's real time monitoring tool, the Streaming API v1, only returned a free 1\% sample (González-Bailón et al., 2014; Hiriart and Martimort, 2012). We were then able to better grasp the social media situation during the response phase. No previous studies have conducted real-time analyses to the best of our knowledge, and most have been relying on samples through the APIs. Some studies produced recommendations for managing social media data during the recovery phase (Pereira et al., 2017; Yin et al., 2015; Zhenlong et al., 2017; Zou et al., 2018), yet they usually fail to considered the application for actual emergency management during the response phase (Crawford and Finn, 2015). Other studies did develop crisis maps based on near-real-time geotweets (Chen et al., 2016; Middleton et al., 2014) but failed to discuss Twitter's API bias. Our results confirm most of the previously discussed biases of SMEM, however emergency-managers and decision-makers are consistently overlooking them in the name of speed, dissemination, multimedia information and citizen engagement.

11 "I'm in Nice there are mutants crowd movements, we don't know why" 
The findings from the three case studies do not fully support such too often unchallenged expectations. Firstly, social media do not enable a faster dissemination of alerts and early warnings, as we have identified systematic delays of one to two hours. The peak of tweets related to the attacks consistently occurred before official accounts issued an alert, and there was no shortage of press alerts in the meantime. Secondly, although social media did foster bottom-up processes, users appealed to the press first, even the few who shared first-hand information and multimedia content; this contributed to eclipsing first-responders and officials accounts. Users reacted to the press in a first phase. Past the first hour, social media boiled down to amplifying political controversies or outrage concerning news coverage, further drowning any information of relevance to emergency management. Thirdly, although extracting only geotagged tweets did not alter the sequence and pattern of the timeline, on-site geotagged information only represented less than $0.5 \%$ of the collected tweets for each event. Fourthly, for each case study, only 3 to 15 Twitter accounts did indeed provide multimedia, context-rich, crowdsourced feedbacks from the scene of the events: first-hand information was very scarce and hard to find amongst the background noise in a timely manner. Furthermore, users were not always able to make sense of the events or images they were reporting. Also, users were not aware of the hashtags, keywords or accounts that could help make their information easier to detect or to localize. Last but not least, first-responders are frequently already at the scene in the case of shared multimedia content, defeating the whole purpose of collecting data on social media for emergency management.

While previous studies did not systematically address the four SMEM biases (fig 1A), some limitations arise from the particular scope and timing of the three European attacks. First, their local extend limited to a couple of neighborhoods over hours (fig 1B) directly affected a relatively limited number of people. The international status of these cities prompted many more people to comment in several languages though, and this might explain our finding of a low in-site geotagged rate. While it could be different in the case of disasters with a wider scope and duration, this has not been examined in the literature yet. Second, the number of affected people (fig 1C) might also impact the signal to noise ratio. During a disaster affecting a larger population, such as major floods or earthquakes, a larger share of social media users might have access to first-hand information which could possibly improve to signal ratio. Again, we have to leave it to conjecture as this has not been thoroughly investigated in previous studies. Third, the security dimension of terror attacks might slow down the dissemination of official information and warnings, enhancing the relevance of SMEM bias 3. It might also generate stronger feelings as we saw with the development of \#prayfor hashtags and attract more political comments (Starbird et al., 2014), lowering the signal to noise ratio as a result. On the other hand, we expect the data repressiveness issue (bias 1) to remain consistent across disaster types and case studies because it might be inherent to social media. We recommend future research to more systematically address these four biases in a variety of case studies to cover the full extent of our proposed SMEM framework while comparing different local governance and geographical context.

Contrasting Twitter 'cultures' in France and Belgium might explain some differences in our results. Unfortunately, to the best of our knowledge, there is no literature on Twitter 'cultures' in Belgium or France, nor a comparison between the two countries, or between the various linguistic communities. However, the police requested in each country the general public to stop sharing information on social media during two major antiterrorist operations in Paris and Brussels consecutive of the 2015 attacks, allowing for a direct comparison: the November $18^{\text {th }}$ assault of a cell in the Saint-Denis suburbs of Paris, and the Brussels' lockdown of November $22^{\text {nd }}$ to carry out arrests of accomplices. In Paris, official Twitter communication kept repeating not to cross the security perimeter and citizens to stop obstructing the operation or sharing pictures and location of police forces. In contrast, in Brussels, the communication was more citizen-inclusive, and the public response more 
social media savvy. Most Brussels related topics on Twitter were flooded by users with cat pictures and jokes that day, in the attempt of drowning out any possible unintentional information leakage. On the next day, Belgian official Twitter accounts followed-up on such humorous means of coping with a crisis situation by thanking the general public with pictures of cat food (Jensen et al., 2020).

By comparing the three case studies, we found that multi-events are different because they are intertwined with information concerning previous events, but with shorter communication delays. Delays in Belgium were always shorter, the crisis center had been working with SMEM since 2013. Regarding the first events to occur, with the exception of the Stade de France failed attack, the highest ratios of users discussing the events were in Zaventem and the city of Nice. The Zaventem case is probably due to circumstances, because of the fortuitous presence of journalists at the airport. Otherwise, in-situ witnesses have, at first, great difficulty interpreting the events, which complicates the detection and crowdsourcing of information, even when images or videos are being shared. The time difference for the press to react is partially explained by the fact that French users tag the press to seek for information, while Belgian users tag the press to prompt it to spread firsthand information. The more comprehensive approach of SMEM in Belgium could explain a halving of the alert times, but warnings were published an hour after the events nonetheless. There is no difference regarding the rate of geotagged tweets in the three case studies. However, analyzing the location of an event using geotweets is not relevant for all cases, as the Paris area was more tagged than the Nice area during the city of Nice attack.

\section{Conclusion}

During the past decade, social media have sparked increasing appeal for improving emergency management. The current focus on social media data collection during days or weeks following disasters is, however, poorly suited to assess real-time SMEM or iVGI usability. Our analysis of top-down, bottom-up and many-to-many Twitter uses during the first hours before and after several recent attacks in France and Belgium raises questions regarding emergency-managers and decisionmakers expectations. While our results confirm most of the biases of SMEM, they also challenge the very reasons why such biases are usually overlooked in the literature and on the ground. Contrary to expectations, first-hand information is easily drowned in the background noise and too often submerged by comments on previous events in the case of multi-event emergencies. In addition, on-site geotagged information only represented an infinitesimal portion of the tweets, even with the most targeted collection. Moreover, the context-rich multimedia shared by users almost systematically depicts first-responders already at the scene and/or users are not always able to make sense of the events they are witnessing in due time. Furthermore, we found a delay of one to two hours between the events and tweets from official accounts, the press consistently being first to alert the public. Users also called upon the press first, overshadowing first-responders, while official accounts lacked the ability to respond to all direct requests. While terror threats have specific time and space settings, it is likely that delays at least equivalent will be found in other emergencies and disasters, in particular those with longer timeframes, such as floods, wildfires, earthquakes or storms. This will require more studies, in different places, with variation among hazards, threats, temporal and analysis scale. We also recommend future research to more systematically address the SMEM four biases to better disentangle what derives from the disaster or case study and what derives from social media and users. We suggest a method to collect Twitter datasets circumventing the API limitations. However, these limitations have recently been reduced with the new Twitter API v2. While it may be possible to reduce warning times by distributing the decision-making or using ready-made messages, more inclusive approaches such as the cell broadcast technology may seem more appropriate for early warning (Aloudat and Michael, 2011). As for the bottom-up flow 
Santoni, V., \& Rufat, S. (2021). How fast is fast enough? Twitter usability during emergencies. Geoforum, 124, $20-35$.

of information, one approach could be to define an official emergency hashtag and to train users; another solution would be to rely on the press to filter out relevant information, since users call upon the press first in any case. In all case studies, emergency managers have been asking the public to switch to social media when their call centers were overloaded. We advise caution as resources might be better spent than looking for weak, scattered, and not necessarily speedier firsthand information on social media.

\section{Reference}

Acar, A., Muraki, Y., 2011. Twitter for crisis communication: lessons learned from Japan's tsunami disaster. Int. J. Web Based Communities 7, 392-402. https://doi.org/10.1504/IJWBC.2011.041206

Albuquerque, J.P. de, Herfort, B., Brenning, A., Zipf, A., 2015. A geographic approach for combining social media and authoritative data towards identifying useful information for disaster management. Int. J. Geogr. Inf. Sci. 29, 667-689. https://doi.org/10.1080/13658816.2014.996567

Aloudat, A., Michael, K., 2011. The application of location-based services in national emergency warning systems: SMS, cell broadcast services and beyond. Presented at the Recent Advances in National Security Technology and Research: Proceedings of the 2010 National Security Science and Innovation Conference, Canberra: Australian Security Research Centre., pp. 21-49.

Bahir, E., Peled, A., 2016. Geospatial extreme event establishing using social network's text analytics. GeoJournal 81, 337-350. https://doi.org/10.1007/s10708-015-9622-x

Beckouche, P., 2019. Les Nouveaux Territoires du numérique, Éditions Sciences Humaines. ed.

Bouillot, F., Poncelet, P., Roche, M., 2012. How and why exploit tweet's location information? Presented at the AGILE International Conference on Geographic Information Science, Springer.

boyd, danah, Crawford, K., 2012. Critical Questions for Big Data. Inf. Commun. Soc. 15, 662-679. https://doi.org/10.1080/1369118X.2012.678878

Bunting, A.M., Stamatel, J., 2019. Exploring geospatial characteristics of hashtag activism in Ferguson, Missouri: An application of social disorganization theory. Geoforum 104, 55-62. https://doi.org/10.1016/j.geoforum.2019.06.008

Chen, X., Elmes, G., Ye, X., Chang, J., 2016. Implementing a real-time Twitter-based system for resource dispatch in disaster management. GeoJournal 81, 863-873. https://doi.org/10.1007/s10708-016-9745-8

Cheng, S., Fang, J., Hristidis, V., Madhyastha, H.V., Mithun, N.C., Perkins, D., Roy-Chowdhury, A.K., Shahbazi, M., Tsotras, V.J., 2016. OSNI: Searching for Needles in a Haystack of Social Network Data 4.

Crampton, J.W., 2015. Collect it all: national security, Big Data and governance. GEOJOURNAL 80, 519-531.

Crawford, K., Finn, M., 2015. The limits of crisis data: analytical and ethical challenges of using social and mobile data to understand disasters. GeoJournal 80, 491-502. https://doi.org/10.1007/s10708-014-9597-z

Crutcher, M., Zook, M., 2009. Placemarks and waterlines: Racialized cyberscapes in post-Katrina Google Earth. Geoforum, Themed Issue: The 'view from nowhere'? Spatial politics and cultural significance of high-resolution satellite imagery 40, 523-534. https://doi.org/10.1016/j.geoforum.2009.01.003

De Longueville, B., Smith, R.S., Luraschi, G., 2009. “OMG, from Here, I Can See the Flames!”: A Use Case of Mining Location Based Social Networks to Acquire Spatio-temporal Data on Forest Fires, in: Proceedings of the 2009 International Workshop on Location Based Social Networks, LBSN '09. ACM, New York, NY, USA, pp. 73-80. https://doi.org/10.1145/1629890.1629907

Douvinet, J., Gisclard, B., Kouadio, J.S., Saint-Martin, C., Martin, G., 2017. Une place pour les technologies smartphones et les Réseaux Sociaux Numériques (RSN) dans les dispositifs institutionnels de l'alerte aux inondations en France ? Cybergeo Eur. J. Geogr. https://doi.org/10.4000/cybergeo.27875

Douvinet, J., Serra-Llobet, A., Kondolf, M., Bopp, E., Péroche, M., 2020. Why keep alert sirens in France? Nat. Hazards Earth Syst. Sci. Discuss. 1-22. https://doi.org/10.5194/nhess-2019-390

Elwood, S., 2008. Volunteered geographic information: future research directions motivated by critical, participatory, and feminist GIS. GeoJournal 72, 173-183. https://doi.org/10.1007/s10708-008-9186-0

González-Bailón, S., Wang, N., Rivero, A., Borge-Holthoefer, J., Moreno, Y., 2014. Assessing the bias in samples of 
Santoni, V., \& Rufat, S. (2021). How fast is fast enough? Twitter usability during emergencies. Geoforum, 124, $20-35$.

large online networks. Soc. Netw. 38, 16-27. https://doi.org/10.1016/j.socnet.2014.01.004

Goodchild, M.F., 2007. Citizens as sensors: the world of volunteered geography. GeoJournal 69, $211-221$. https://doi.org/10.1007/s10708-007-9111-y

Graham, M., Hale, S.A., Gaffney, D., 2014. Where in the World Are You? Geolocation and Language Identification in Twitter. Prof. Geogr. 66, 568-578. https://doi.org/10.1080/00330124.2014.907699

Graham, M.W., Avery, E.J., Park, S., 2015. The role of social media in local government crisis communications. Public Relat. Rev. 41, 386-394. https://doi.org/10.1016/j.pubrev.2015.02.001

Hiriart, Y., Martimort, D., 2012. Le citoyen, l'expert et le politique : une rationalité complexe pour une régulation excessive du risque. Ann. Econ. Stat. 153-182. https://doi.org/10.2307/23646357

Jensen, M.S., Neumayer, C., Rossi, L., 2020. 'Brussels will land on its feet like a cat': motivations for memefying \#Brusselslockdown. Inf. Commun. Soc. 23, 59-75. https://doi.org/10.1080/1369118X.2018.1486866

Jones, N.M., Thompson, R.R., Schetter, C.D., Silver, R.C., 2017. Distress and rumor exposure on social media during a campus lockdown. Proc. Natl. Acad. Sci. 114, 11663-11668. https://doi.org/10.1073/pnas.1708518114

Kitchin, R., Lauriault, T.P., 2015. Small data in the era of big data. GeoJournal 80, $463-475$. https://doi.org/10.1007/s10708-014-9601-7

Kryvasheyeu, Y., Chen, H., Moro, E., Hentenryck, P.V., Cebrian, M., 2015. Performance of Social Network Sensors during Hurricane Sandy. PLOS ONE 10, e0117288. https://doi.org/10.1371/journal.pone.0117288

Kryvasheyeu, Y., Chen, H., Obradovich, N., Moro, E., Hentenryck, P.V., Fowler, J., Cebrian, M., 2016. Rapid assessment of disaster damage using social media activity. Sci. Adv. $2, \quad$ e1500779. https://doi.org/10.1126/sciadv.1500779

Kusumo, A.N.L., Reckien, D., Verplanke, J., 2017. Utilising volunteered geographic information to assess resident's flood evacuation shelters. Case study: Jakarta. Appl. Geogr. 88, 174-185. https://doi.org/10.1016/j.apgeog.2017.07.002

Landwehr, P.M., Wei, W., Kowalchuck, M., Carley, K.M., 2016. Using tweets to support disaster planning, warning and response. Saf. Sci., Building Community Resilience to Global Hazards: A Sociotechnical Approach 90, 33-47. https://doi.org/10.1016/j.ssci.2016.04.012

Latonero, M., Shklovski, I., 2011. Emergency Management, Twitter, and Social Media Evangelism: Int. J. Inf. Syst. Crisis Response Manag. 3, 1-16. https://doi.org/10.4018/jiscrm.2011100101

Li, L., Goodchild, M.F., Xu, B., 2013. Spatial, temporal, and socioeconomic patterns in the use of Twitter and Flickr. Cartogr. Geogr. Inf. Sci. 40, 61-77. https://doi.org/10.1080/15230406.2013.777139

Liu, S.B., Palen, L., Sutton, J., Hughes, Amanda L., Liu, S.B., Palen, L., Sutton, J., Hughes, A. L., Vieweg, S., 2008. The Emergent Role of On-Line Photo Sharing in Times of Disaster. Presented at the Iscram.

Luo, F., Cao, G., Mulligan, K., Li, X., 2016. Explore spatiotemporal and demographic characteristics of human mobility via Twitter: A case study of Chicago. Appl. Geogr. 70, 11-25. https://doi.org/10.1016/j.apgeog.2016.03.001

Middleton, S.E., Middleton, L., Modafferi, S., 2014. Real-Time Crisis Mapping of Natural Disasters Using Social Media. IEEE Intell. Syst. 29, 9-17. https://doi.org/10.1109/MIS.2013.126

Okolloh, O., 2009. Ushahidi, or "testimony": Web 2.0 tools for crowdsourcing crisis information. Change Hand Web 20 Dev. 59, 65-70.

Palen, L., Vieweg, S., Liu, S., Hughes, A., 2009. Crisis in a Networked World. Soc. Sci. Comput. Rev. - SOC SCI COMPUT REV 27, 467-480. https://doi.org/10.1177/0894439309332302

Pereira, J., Pasquali, A., Saleiro, P., Rossetti, R., 2017. Transportation in Social Media: An Automatic Classifier for Travel-Related Tweets, in: Oliveira, E., Gama, J., Vale, Z., Lopes Cardoso, H. (Eds.), Progress in Artificial Intelligence, Lecture Notes in Computer Science. Springer International Publishing, Cham, pp. $355-366$. https://doi.org/10.1007/978-3-319-65340-2_30

Rive, G., Hare, J., Thomas, J., Nankivell, K., 2012. Social Media in Emergency: A Best Practice Guide.

Sakaki, T., Okazaki, M., Matsuo, Y., 2010. Earthquake shakes Twitter users: real-time event detection by social sensors, in: Proceedings of the 19th International Conference on World Wide Web, WWW '10. Association for Computing Machinery, Raleigh, North Carolina, USA, pp. 851-860. https://doi.org/10.1145/1772690.1772777

Saldana-Perez, M., Cavalière, C., Torres-Ruiz, M., Moreno-Ibarra, M., 2019. When Twitter Becomes a Data Source for 
Santoni, V., \& Rufat, S. (2021). How fast is fast enough? Twitter usability during emergencies. Geoforum, 124, $20-35$.

Geospatial Analysis 18 .

Santoni, V., Audoin, L., 2017. De l'urgence d'une cartographie de crise au centre de crise zonal, in: EU SEquana; La Gestion de Crise à l'épreuve de l'exercice.

Shelton, T., 2017. Spatialities of data: mapping social media 'beyond the geotag.' GeoJournal 82, 721-734. https://doi.org/10.1007/s10708-016-9713-3

Shelton, T., Poorthuis, A., Graham, M., Zook, M., 2014. Mapping the data shadows of Hurricane Sandy: Uncovering the sociospatial dimensions of 'big data.' Geoforum 52, 167-179. https://doi.org/10.1016/j.geoforum.2014.01.006

Spence, P.R., Lachlan, K.A., Lin, X., Greco, M. del, 2015. Variability in Twitter Content Across the Stages of a Natural Disaster: Implications for Crisis Communication. Commun. Q. 63, 171-186. https://doi.org/10.1080/01463373.2015.1012219

Starbird, K., Maddock, J., Orand, M., Achterman, P., Mason, R.M., 2014. Rumors, False Flags, and Digital Vigilantes: Misinformation on Twitter after the 2013 Boston Marathon Bombing. https://doi.org/10.9776/14308

Takahashi, B., Tandoc, E.C., Carmichael, C., 2015. Communicating on Twitter during a disaster: An analysis of tweets during Typhoon Haiyan in the Philippines. Comput. Hum. Behav. 50, 392-398. https://doi.org/10.1016/j.chb.2015.04.020

Takhteyev, Y., Gruzd, A., Wellman, B., 2012. Geography of Twitter networks. Soc. Netw., Capturing Context: Integrating Spatial and Social Network Analyses 34, 73-81. https://doi.org/10.1016/j.socnet.2011.05.006

Tsou, M.-H., 2015. Research challenges and opportunities in mapping social media and Big Data. Cartogr. Geogr. Inf. Sci. 42, 70-74. https://doi.org/10.1080/15230406.2015.1059251

Tsou, M.-H., Leitner, M., 2013. Visualization of social media: seeing a mirage or a message? Cartogr. Geogr. Inf. Sci. 40, 55-60. https://doi.org/10.1080/15230406.2013.776754

Vicario, M.D., Bessi, A., Zollo, F., Petroni, F., Scala, A., Caldarelli, G., Stanley, H.E., Quattrociocchi, W., 2016. The spreading of misinformation online. Proc. Natl. Acad. Sci. 113, 554-559. https://doi.org/10.1073/pnas.1517441113

Wang, Z., Lam, N.S.N., Obradovich, N., Ye, X., 2019. Are vulnerable communities digitally left behind in social responses to natural disasters? An evidence from Hurricane Sandy with Twitter data. Appl. Geogr. 108, 1-8. https://doi.org/10.1016/j.apgeog.2019.05.001

Williams, E., Gray, J., Dixon, B., 2017. Improving geolocation of social media posts. Pervasive Mob. Comput., Special Issue on Pervasive Social Computing 36, 68-79. https://doi.org/10.1016/j.pmcj.2016.09.015

Yin, J., Karimi, S., Lampert, A., Cameron, M., Robinson, B., Power, R., 2015. Using Social Media to Enhance Emergency Situation Awareness: Extended Abstract 5.

Yuan, Y., Lu, Y., Chow, T.E., Ye, C., Alyaqout, A., Liu, Y., 2020. The Missing Parts from Social Media-Enabled Smart Cities: Who, Where, When, and What? Ann. Am. Assoc. Geogr. 110, $462-475$. https://doi.org/10.1080/24694452.2019.1631144

Zhang, G., Zhu, A.-X., 2018. The representativeness and spatial bias of volunteered geographic information: a review. Ann. GIS 24, 151-162. https://doi.org/10.1080/19475683.2018.1501607

Zhao, L., Chen, F., Lu, C.-T., Ramakrishnan, N., 2016. Online Spatial Event Forecasting in Microblogs. ACM Trans. Spat. Algorithms Syst. TSAS 2, 15:1-15:39. https://doi.org/10.1145/2997642

Zhenlong, L., Cuizhen, W., Emrich, C.T., Guo, D., 2017. A novel approach to leveraging social media for rapid flood mapping: a case study of the 2015 South Carolina floods. Cartogr. Geogr. Inf. Sci. 1-14.

Zook, M., Graham, M., Shelton, T., Gorman, S., 2010. Volunteered Geographic Information and Crowdsourcing Disaster Relief: A Case Study of the Haitian Earthquake. World Med. Health Policy 2, 7-33. https://doi.org/10.2202/1948-4682.1069

Zou, L., Lam, N.S.N., Cai, H., Qiang, Y., 2018. Mining Twitter Data for Improved Understanding of Disaster Resilience. Ann. Am. Assoc. Geogr. 108, 1422-1441. 